Illinois State University

ISU ReD: Research and eData

Theses and Dissertations

3-17-2015

\title{
Utilizing Illinois State University's Environmental Legacy and Historical Collections to Sustain a Global Future
}

Melissa Nergard

Illinois State University, mashall@ilstu.edu

Follow this and additional works at: https://ir.library.illinoisstate.edu/etd

Part of the Environmental Sciences Commons, and the History of Science, Technology, and Medicine Commons

\section{Recommended Citation}

Nergard, Melissa, "Utilizing Illinois State University's Environmental Legacy and Historical Collections to Sustain a Global Future" (2015). Theses and Dissertations. 353.

https://ir.library.illinoisstate.edu/etd/353

This Thesis is brought to you for free and open access by ISU ReD: Research and eData. It has been accepted for inclusion in Theses and Dissertations by an authorized administrator of ISU ReD: Research and eData. For more information, please contact ISUReD@ilstu.edu. 


\section{UTILIZING ILLINOIS STATE UNIVERSITY'S ENVIRONMENTAL LEGACY AND HISTORICAL COLLECTIONS \\ TO SUSTAIN A GLOBAL FUTURE}

$\begin{array}{ll} & \text { Melissa A. Nergard } \\ 97 \text { Pages } & \text { May } 2015\end{array}$

The scholarly capital of materials at Illinois State University includes numerous natural history collections from the mid-nineteenth century that hold significant research and historical value. Changes in pedagogical methods and academic leadership, however, created confusion and territorial competition in who would preserve and manage the collections. Consequently some specimens from those early collections have been both lost and forgotten. This thesis used a systems approach to track the material losses incurred when institutional support shifted in the 1870s, and the original collectors and curators left Central Illinois for national interests in Washington, D.C. Yet, historical environmental collections have become increasingly valuable sources of data for researchers as the specimens and collector notes enable scientists to determine anthropogenic influences on environmental systems on a global scale. Curators currently face significant challenges in maintaining these collections and making them available for global research. Lack of consistent funding, dedicated time, physical space, and awareness of the significance of the specimens has left the collections diminished and threatens their future. This thesis provides an historical overview of these significant 
collections and an analysis of the contemporary concerns that could benefit from the scientific wealth in these specimens 
UTILIZING ILLINOIS STATE UNIVERSITY'S ENVIRONMENTAL

LEGACY AND HISTORICAL COLLECTIONS

TO SUSTAIN A GLOBAL FUTURE

MELISSA A. NERGARD

A Thesis Submitted in Partial

Fulfillment of the Requirements for the Degree of

MASTER OF ARTS

Department of History

ILLINOIS STATE UNIVERSITY

2015 
(C) 2015 Melissa A. Nergard 
UTILIZING ILLINOIS STATE UNIVERSITY'S ENVIRONMENTAL

LEGACY AND HISTORICAL COLLECTIONS

TO SUSTAIN A GLOBAL FUTURE

MELISSA A. NERGARD

COMMITTEE MEMBERS:

Kyle Ciani, Chair

Roger Biles

Joan Brehm 


\section{ACKNOWLEDGMENTS}

I would like to thank Dr. Kyle Ciani, Dr. Roger Biles and Dr. Joan Brehm for their expertise and patience in serving on my thesis committee. I would also like to thank Dr. Angelo Capparella and Dr. Joe Armstrong for working so diligently to maintain the natural history collections and preserve the institution's historical resources.

M.A.N. 


\section{CONTENTS}

\section{Page}

ACKNOWLEDGMENTS $\quad$ i

$\begin{array}{ll}\text { CONTENTS } & \text { ii }\end{array}$

$\begin{array}{ll}\text { TABLES } & \text { iii }\end{array}$

FIGURES $\quad$ iv

CHAPTER

I. NATURAL BEGINNINGS, ILLINOIS STATE UNIVERSITY'S ENVIRONMENTAL LEGACY 1

II. THE FORMATION OF THE NATURAL HISTORY COLLECTION 20

III. CURATORS AND COLLECTORS: THE MEN WHO REALLY MADE THE COLLECTION 34

IV. RESEARCH AND POLICY USING BIOLOGICAL SPECIMENS 60

V. CHANGING HISTORY: THE SECRETS IN DRAWERS AND CLOSETS 84

$\begin{array}{lr}\text { BIBLIOGRAPHY } & 90\end{array}$ 


\section{TABLES}

Table $\quad$ Page

1. Number of Published Articles Using Biological Collections 17

2. Weights of Raptor Eggshells in Museum and Private Collections 63

3. DDE Residue in Peregrine Falcon Eggs 65

4. Examples of Databases of Bio-Informatics 87 


\section{FIGURES}

Figure $\quad$ Page

1. Example of 1860 Course Offerings 3

2. Photo of Grizzly Bear Specimen Obtained by Powell 12

3. Commissions of the INHS 22

4. Photo of Old Main Building 27

5. Specimen Collected by George S. Vasey 40 


\section{CHAPTER I}

\section{NATURAL BEGINNINGS, ILLINOIS STATE UNIVERSITY'S ENVIRONMENTAL LEGACY}

On top of a book shelf on the $6^{\text {th }}$ floor of Illinois State University's Milner Library sits a snowy owl encased in a portable, yet unwieldy, glass display case. The specimen is estimated to be over 150 years old, collected during a significant irruption in the nineteenth century. In the case of snowy owls, this population explosion pushed the raptors thousands of miles from their native Arctic habitat. ${ }^{1}$ This event occurred at a time when the natural sciences were developing as professional disciplines, and a growing nation was cataloging its vast biological resources. The owl's longevity as an object of study has far exceeded the years it had lived as a significant and reclusive predator, yet over the course of the last century and a half the owl's value to science has only begun to be realized. The short life of this raptor, and its subsequent preservation, might very well ensure the viability of its species as well as our own.

This thesis will assess the significance of the various scientific collections housed at Illinois State University in relation to their contribution to the development of curriculums taught at the university; including environmental, sustainability and natural history. The specimens represent and embody a wealth of biological data within the

\footnotetext{
${ }^{1}$ Angie McPherson, "What a Hoot: Snowy Owls Make Rare Southern Appearance,” National Geographic, January 22, 2014. Accessed August 24, 2014. http://news.nationalgeographic.com/news/2014/01/140122-snowy-owl-south-united-states-irruptionmigration-photos-science/.
} 
dried remnants of plants, preserved skins and stomachs, and drawers of rocks. However, that is not where their contributions end. Each of these collections also tells the history of humans, science, the environment, and Illinois State University as it exists today. They hold information that can help determine the future almost as well as they elucidate the past, but the institutional support provided to maintain them is deficient. The University by its very nature is responsible for education, research, and developing a knowledgeable and engaged citizenry. Withholding the information available in the collections from the global research community, whether through wonton disregard or resource limitations, is contradictory to the institution's mission.

The collections were originally established in the mid-nineteenth century for use by researchers and collectors in the biological and natural sciences. Intended as a pedagogical tool for university students and the growing public school systems of Illinois, the collections benefited from numerous private collectors providing a vast number of specimens for distribution throughout the state. These collections continue to be utilized for research and educational purposes, and while their prominence as a scholarly resource has fluctuated over the course of the 150 year history of ISU, their potential value as an institutional and global resource has never been higher than it is today. There is a critical need in the twenty-first century to understand how the planet's environmental systems work, and how humans have inadvertently triggered catastrophic changes in those systems. The historical record of human ecology can be found in natural history collections. 


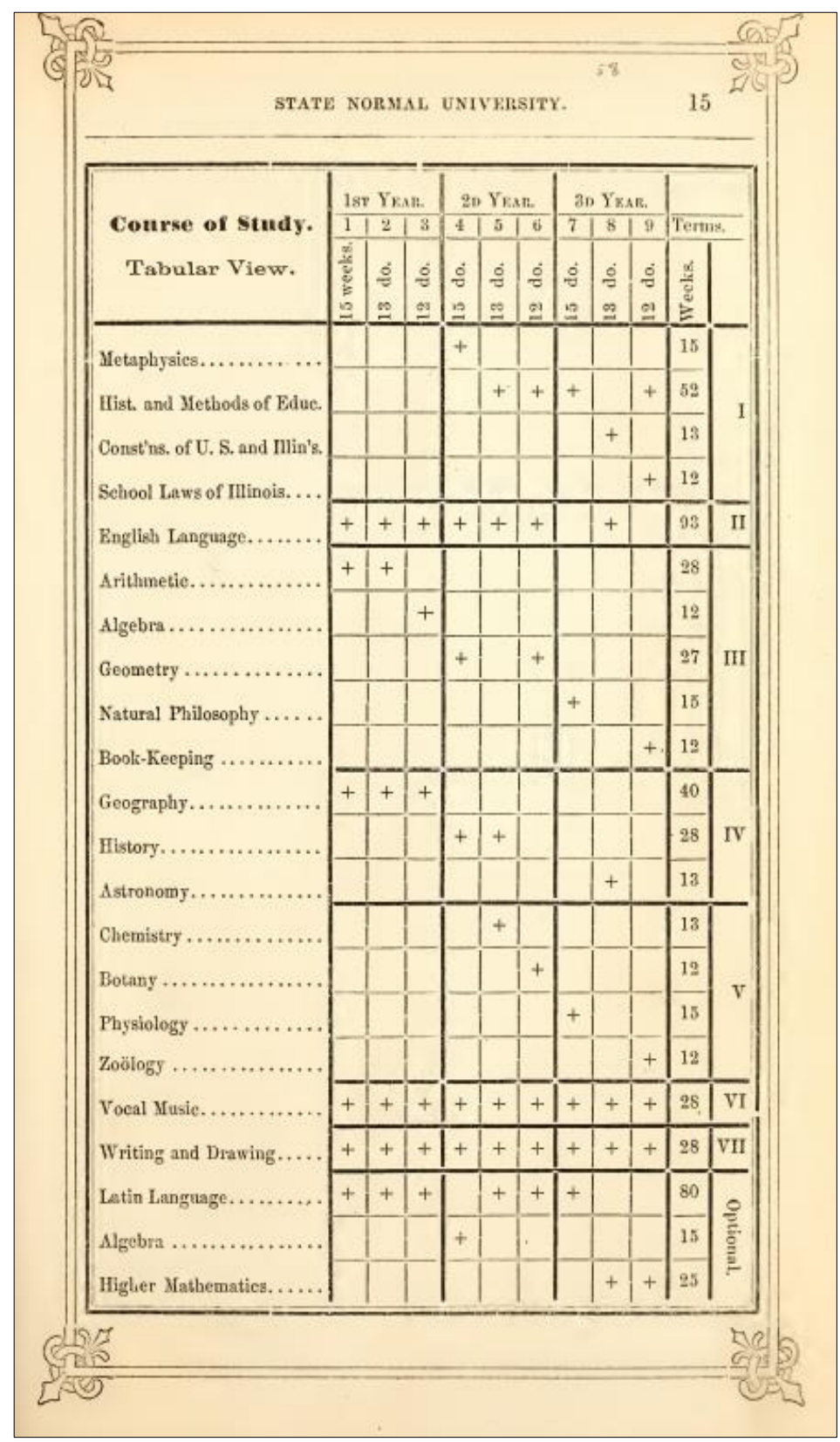

Figure 1: Example of 1860 Course Offerings.

Source: Illinois State Normal University Course Catalog, 1860

Records regarding the collection were obtained by reviewing the minutes of the Illinois Natural History Society, reports from the boards and societies, legislative actions, and institutional records. 
The founders and curators of the collections are well published and their own works were utilized to gather pieces of the history. Biographies, papers they authored, government records of exploration surveys, and private correspondence demonstrated their relationship to ISU, their role in the collections, and their contributions to research and policy. There has been a renewed interest in, and use of, natural collections in research for the purposes of demonstrating human influenced changes in the environment. The collections provide opportunities to build a historical timeline of anthropogenic activity on scalable geographic ranges. This allows researchers to track the impact of an action or event from its beginning, and then track it over time and distance. This helps to identify the tipping points for eco-system events and species declines or extinctions. Some of the earliest research for this purpose began in the midtwentieth century, but by the end of the century the effects of climate change prompted an increase in utilization of the specimens. The need for viable research specimens also initiated an international effort to make the data gleaned from specimens available electronically so that any researcher can access a dataset on any specimen anywhere in the world.

Utilizing the snowy owl as representative of specimens available in collections around the world, the history of environmental research and human interactions with the environment can be examined. For instance, the snowy owl was most likely made available for university students in the premiere museum facility housed in the University's first campus building, Old Main. In 1858 the museum held significant prominence and the entire third floor of the building was dedicated to the collections. One hundred years later the specimens that had not been dispersed, separated into 
discipline-specific collections, or destroyed, found their way into the teacher education program at Milner Library for use by aspiring educators. Specimens came complete with a prepared curriculum and were utilized as display models, providing access to animals that most students would never have the opportunity to see in their native environs.

The snowy owl is an example of a bird rarely seen in the lower 48 states, and it is one of the more significant specimens in the collection due to the fact that it was collected outside of its normal range. Unfortunately, its misfortune at being in the wrong place at the wrong time continued. In the 1970's the stuffed raptor was made available to aspiring teachers and it spent the next forty years transported in bouncing cars, banged around while being handled, placed on display in sunlight and heat, and alternately stored in dark, leaky rooms. ${ }^{2}$ The condition in which the owl has been maintained threatens the additional knowledge it has the potential to provide. Beyond a standardized curriculum that explains its role, habits, prey, and reproductive cycle, the latent pedagogy of the bird lay dormant. The true potential for scholars lay hidden in its DNA and the chemical traces trapped in its feathers. It can be found in the history and provenance of a bird collected on an expedition over 150 years ago, when land use and climate were vastly different. Within this owl lies a wealth of knowledge for today's scholars and analysts, policy makers, and climatologists. This owl is just one specimen among thousands who's potential to inform and educate remains encased in a glass box, hidden in a closet of the library.

\footnotetext{
${ }^{2}$ Milner Library at Illinois State University utilized some of the original Powell specimens as part of its teacher education program until 2012. Specimens and corresponding curricular aids were loaned out to teachers for use in classroom education.
} 
Over 150 years after the snowy owl was preserved, the setting in which the bird is situated has not changed but the curriculum regarding the species is more robust and expansive. A great deal of knowledge regarding environmental systems has been gained since the original Illinois State Natural History (ISNH) museum was formed, yet the same specimens are being utilized for teacher education. The lack of awareness regarding the expanded educational and research value of the specimens provides support for the need to properly curate the environmental collections.

The curators of the original ISNH collections had also been the collectors, researchers and professors. As the collection was dispersed some specimens remained in the research realm, others became part of the educational displays, and portions of collections were sent to other state institutions. The curatorial responsibilities were dispersed with the items and the various collections became purposed for the departments in which they were housed. Overall, they became the purview of both librarians and professors, two groups working largely independently of each other.

Over the course of the institution's history the provenance of the library specimens was lost, and their identity as part of a larger collection was forgotten. The preserved animals, fossils, skeletons and skins in the library collection fundamentally became museum objects and teaching aids - static displays with a 'look, but do not touch' protective shell, while the research specimens were tucked away in laboratories and climate controlled storage rooms accessible only to those with proper credentialing and academic interests.

A recurrent theme, which will be explored in more depth in later chapters of this thesis, is the fluctuating perception of the value of natural history collections. The 
University continued to accept contributions of specimens even after significant portions of the holdings had been dispersed following the closing of the original INHS museum. The most prominent of these was a large geological specimen collection donated by the Funk family in 1969. Sadly, this collection was also dispersed when the University's museum was closed again in the 1980's. ${ }^{3}$ Although the Geography/Geology Department maintains a considerable portion of the original donation many specimens were given to the State of Illinois, and the rest were dispersed across campus, and not necessarily to academic departments. A set of very large geodes are actually used in the landscaping outside of the west door of the Felmley Hall of Science. In addition to the specimens associated with natural sciences, the University has been the recipient of many other types of collections and artifacts. A 1953 newsletter titled "Museum Notes" lists collections from the social sciences, arts, music, and home economics. ${ }^{4}$ These types of collections gained prominence and were curated by the library staff.

Arguably the university's most renowned collection is the Circus Collection. It continues to receive significant contributions from private donors as a result of the work of the special collections unit at Milner Library. Milner Library has staff dedicated to the preservation and use of special collections, the facilities have been upgraded to properly store the materials, and there are staff assigned to promote the collection and procure additional items. Conversely, the Natural Science collections which used to be the premiere collection of the campus, suffers from a lack of cohesive and systematic

\footnotetext{
${ }^{3}$ The complete history of the museum is difficult to discern due to a lack of records, however two campus newsletters titled "Museum Notes" indicate that the museum had been reestablished in or slightly before 1946. The newsletters are held in the private papers of the former curator of the museum, Dr. Marcia Young, Bloomington, IL. (From this point forward referred to as "Young papers.")

4 “Museum Notes," Illinois State University (October 1953). Held in the personal papers of Young.
} 
cataloging, protocol for use and collaborative advocacy. The natural history collections are curated by faculty, some emeritus, who are only marginally able to dedicate time to the collections given their primary commitments to teaching, research and service.

The loss of interest in the natural history collections began in the early 1900's when their pedagogical value declined due to changing theories on education and the role of science. The history of teaching theory and methodologies is too broad to fit into this study, but it is impactful to the specimens and is reflected in how the collections fared during their tenure at the university. In a paper received by the Office of the President of Illinois State University in 1964 on the history of the biological sciences at Illinois State, an unknown author states that, "The routine aspects of the biological sciences during the ensuing 75 years remained relatively strong in comparison with other Normal schools, although the vital elements of research and original inquiry became almost nonexistent." ${ }^{, 5}$ This statement reflects the diminishing use and value of the laboratory collections.

Pedagogical methods had evolved from those utilized in the nineteenth century. When the specimens were first utilized, the preferred method of teaching was in a classroom in controlled conditions. Methods transformed over time and moving outside of the building and into the environment became the preferred method of learning. The irony of this lies in the inverse relationship of natural sciences in education as it relates to the availability of healthy environmental systems for students to observe.

At the University's founding in 1857 , it was a time in the nation's history when ecology was still fairly close to its native state across much of the continent, particularly

\footnotetext{
5 “A Brief History of Biological Sciences at I.S.U.” Received by the Office of President I.S.U., August 11, 1964. Young papers.
} 
in the west. ${ }^{6}$ Yet the intense scrutiny of nature was most predominantly accomplished by capturing specimens, killing, preserving and cataloguing them. Individual animals and plants were removed from their environs as if they were stand-alone creatures. These excised specimens were then gathered together, sorted by observable physical characteristics, and made available for educators to use in classrooms to teach students about the natural world. The cataloguing and classifying of the animals and plants was made outside of their native environments, based on traits and characteristics that often excluded behavior, life cycle, species relationships and other relevant biological data.

Museum displays followed in similar fashion, presenting the animals removed from the ecosystem, typically in cases displaying similar species, but fundamentally as organisms that exist separate from the natural system in which they had been indelibly integrated. While museums have been, and to some extent continue to be, more tailored to entertainment, universities have always held a niche as intellectual bastions, centers of knowledge and research. The curators of the original ISNH collections had also been the collectors, researchers and professors. As the collection was dispersed, some specimens remained in the research realm, and others became part of educational displays. The curatorial responsibilities diverged and the various collections became purposed for the departments in which they were housed. Overall, they became the purview of both librarians and professors, two groups working largely independently of each other.

Museums provide universal, yet limited, access to biological life and history. Conversely laboratories provide limited, yet potentially universal, access to a host of

\footnotetext{
${ }^{6}$ In regard to the use of the term 'native state,' it is intended to incorporate the ecological systems as they existed including the interactions of the indigenous populations within the habitat, but prior to the impacts of non-native settlers. It is not intended to portray a non-anthropogenically influenced ecosystem.
} 
scientific and educational information. Time, proximity, and money prevent the collection, dissemination and use of that data. In the nineteenth century, when these specimens were collected, there was more access to relatively natural ecosystems than at any point in time since then, but the value of those systems was not realized. In the twenty-first century these specimens are necessary to provide the history of those same degraded ecosystems in order to understand how they worked. Regardless of where the specimens are housed or which unit has maintained them, they are just as integral to understanding the ecosystems today as they were a century and a half ago. The impact of European settlers has forever changed the natural systems, making the specimens and research of the nineteenth century incredibly valuable, including those specimens in the library and academic departments at Illinois State University. It is no small tragedy that they continue to be excluded from researching the systems that they inherently belong to and can affect the most.

Fortunately, in the twenty-first century the roles of university, library and museum collections have a renewed place in the teaching of environmental science.

Steven Conn, author of Museums and American Intellectual Life, 1876-1926, notes that:

In fulfilling their public educational mission, many natural history museums now include exhibits dealing with environmental degradation, endangered species, and the like. And this has given their specimens an ironic relevance. Many of the birds, butterflies, mammals, and reptiles collected in the nineteenth century to be metonymic now increasingly stand as unique, rare, and lonely. They are no longer representative of the natural world as it is, but as it was. ${ }^{7}$

\footnotetext{
${ }^{7}$ Steven Conn, Museums and American Intellectual Life, 1876-1926 (Chicago: The University of Chicago Press, 1998).
} 
Over the decades the museum and laboratory collections fell into disuse; being stored away in attics and basements, and then decaying due to pests and neglect. Unfortunately, the same loss of value is reflected in the state of the Illinois State University archives, which once held the collection notes of John Wesley Powell's many contributions. The notes, as will be discussed later, have as much significance as the specimens themselves but they have been lost and, as of 2014, are currently unaccounted for.

The absence of the documents has contributed to difficulty in obtaining information on the history and provenance of the specimens in the collections throughout the Illinois State campus. However, the work of the renowned nineteenth century scientist has not all been lost to time and memory. Despite the lack of regard for the collections during several eras of the university's history, some specimens were well curated in the scattered collections. Many are used for laboratory research, others are displayed as representative pieces of the larger collections, and several single cabinet displays occupy various hallways and buildings. In the hallway outside of ISU's Department of Biological Sciences there is a display of a black bear collected on John Wesley Powell's first survey of the west. Although its presentation seems forlorn and the specimen poorly preserved, it is one of the campus' most visible markers of Powell's influence and legacy. 


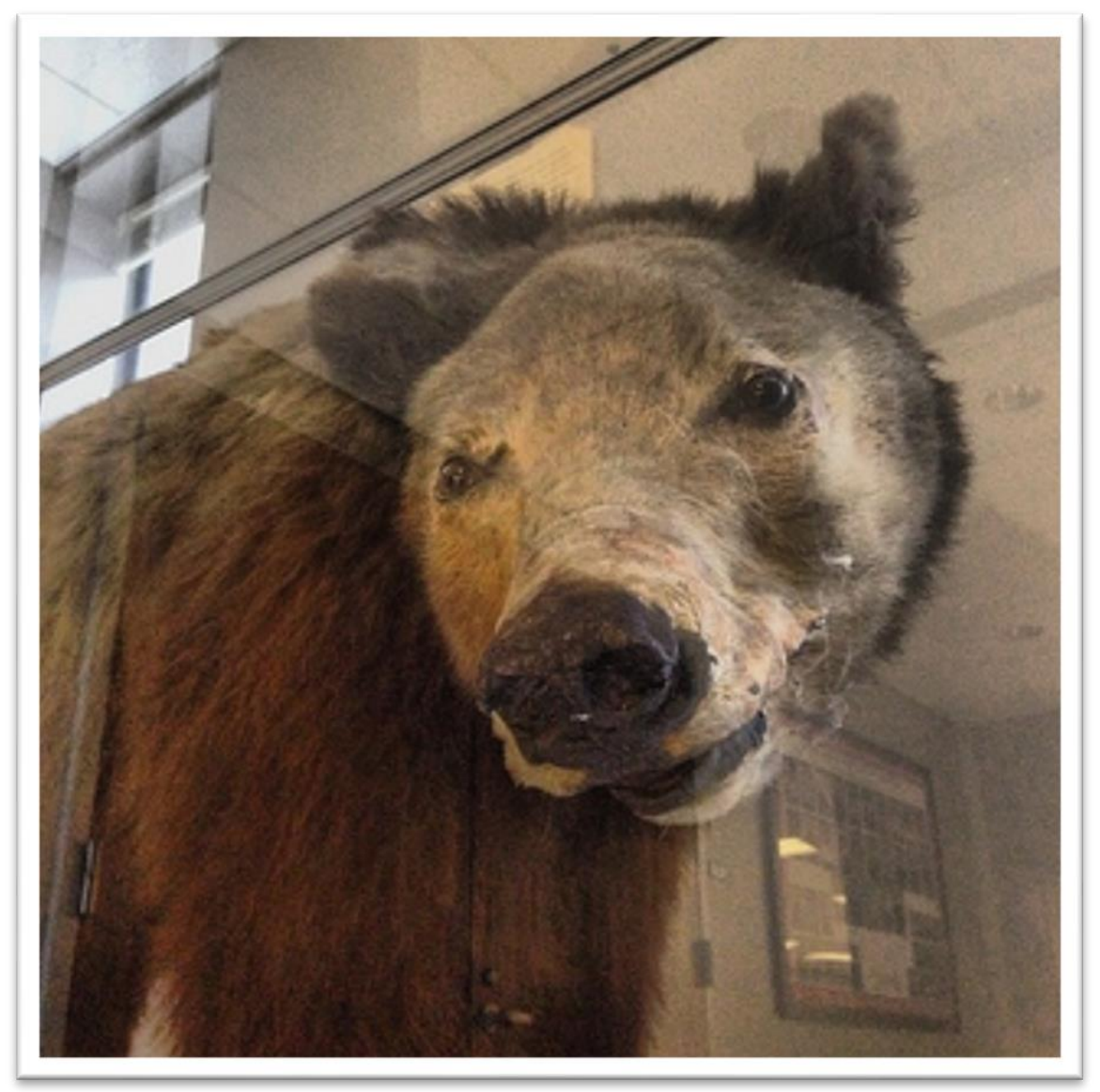

Figure 2: Photo of Grizzly Bear Specimen Obtained by Powell.

This specimen is on display on the second floor of Julian Hall at Illinois State University. ${ }^{8}$

Displaying specimens helps to promote the collections and ISU's historical legacy

to a larger public. In her research on the delicate art of balancing education and

conventional museum responsibilities, Danielle Rice touches on the roles that society has

\footnotetext{
${ }^{8}$ The typed paper with the display reads "The grizzly (Ursus Arctos) originally ranged from the great plains westward in North America. Throughout its range this large bear varied greatly with regard to size and color. This led early mammalogists to describe many forms and at one time 87 named "species" were recognized. Today most authorities agree that the grizzly probably was represented by one wide-ranging variable species, and many people now recognize the grizzly, the big brown bear of Alaska and the old world brown bear as races of the same species. In the United States the grizzly now thrives only in the vicinity of Glacier and Yellowstone National Parks. They are still common locally in Alaska and Western Canada. A few individuals may still survive in California and Northern Mexico. Adult individuals are 6 to $7 \frac{1}{2}$ feet long and stand 3 to $3 \frac{1}{2}$ feet high at the shoulders. Adult males usually weigh about 500 pounds, females 400 , but wild individuals up to 800 pounds have been recorded."
} 
implicitly assigned to institutions of education and to museums. In the past century the need to reconnect with the general public to generate funding, both private and public, has led to the reassessment of the place and manner of education in museums. ${ }^{9}$ Likewise, the need for funding has pushed universities and colleges to demonstrate that students have experience applying what they have learned, especially in regard to best teaching practices. Consequently, practical, thought provoking, and innovative education has become the core component to the survival of both institutions. Addressing a new, interdisciplinary methodology to meet the needs of an evolving citizenry must also incorporate the quick pace of today's lifestyles. Both types of institutions must contend with the rapid integration of technology which has further obscured the traditional roles and scopes of brick and mortar campuses.

Illinois State University's guiding doctrine, Educating Illinois, addresses this need for adaptability and momentum. The institution has specific goals and strategies to "Provide rigorous, innovative, and high-impact undergraduate and graduate programs that prepare students to excel in a globally competitive, culturally diverse, and changing environment." The strategies to attain this goal include increasing research opportunities, applications for external funding, international partnerships, inter-disciplinary collaboration, and enhanced globalization of the campus and curriculum. ${ }^{10}$ The collections provide the institution an opportunity to use an existing research to contribute to these goals.

\footnotetext{
${ }^{9}$ Danielle Rice, "Balancing Act: Education and the Competing Impulses of Museum Work," Art Institute of Chicago Museum Studies 29, no. 1, Museum Education at the Art Institute of Chicago (2003): 11.

10 “Educating Illinois 2013-2018," Illinois State University, accessed February 22, 2015, http://educatingillinois.illinoisstate.edu/strategies/\#tabs-accord2.
} 
There is a strong environmental and scientific component to the collections and research surrounding historic specimens. Nearly a century and a half after John Wesley Powell's initial explorations into the western half of the United States, the environmental and human interactions (now called human ecology) that he studied are still at the forefront of many current and very heated debates. As Elizabeth Yakel discusses in her research on the Smithsonian Institution's Enola Gay exhibition, debates can prove to be controversial to the point that they are detrimental to an exhibit. ${ }^{11}$ In itself controversy is an area with which experienced museum staff take a proactive approach in designing exhibits, and as an added educational opportunity it can provide very practical experience for students in communications, public relations, marketing and journalism. Jeffrey K. Stine also discusses formulating exhibits around controversy - not necessarily causing it, but analyzing the perspectives of all sides to adequately create a comprehensive exhibit. Stine states that controversy can be leveraged in a way that "engages the public."12 Combining the expertise and knowledge of museum staff and university faculty allows for an enriching and unique experience for students of all disciplines.

In an article on "The Role of Museums and Material Culture Collections in American Studies," the authors note that there needs to be a level of exchange that occurs between the exhibit and the patron; however current museum practices often discourage such physical dialogue (for the protection of the object). ${ }^{13}$ Museum exhibits geared

\footnotetext{
${ }^{11}$ Elizabeth Yakel, "Museums, Management, Media, and Memory: Lessons from the Enola Gay Exhibition," Libraries \& Culture 35, no. 2 (2000): 278-310.

12 Jeffrey K. Stine, "Placing Environmental History on Display," Environmental History 7, no. 4 (2002): 569.

${ }^{13}$ Linna Funk Place, et.al., "The Object as Subject: The Role of Museums and Material Culture Collections in American Studies," American Quarterly, vol. 26, no. 3 (August 1974): 281-294.
} 
toward adult learners typically display an object and then provide information related to it, but there is little opportunity for engagement. Children's museums have mastered the educational component of exhibits, creating interactive displays and encouraging learning in methods other than reading a carefully prepared placard. Museum scholars now call for innovation and collaboration, pointing to partnerships between museums and universities in creating educational programs, sometimes for academic credit. These partnerships benefit everyone involved, including the museum patrons. Fresh eyes provide new perspectives and creativity breeds learning. Non-traditional approaches are in themselves learning opportunities, for they require thought, encourage problemsolving, and demand excellent communication, with a little bit of risk-taking thrown in for good measure.

Yakel also provides perspective on the social and cultural aspects of collections and discusses the role of memory and personal experience in a museum visitor's approach to any exhibit. Yakel, as well as Rice and Stine, stress the importance of psychology and research methodology in both designing exhibits as well as measuring their impact. These are key considerations to an exhibit, and demonstrating the public's interest is a core component to funding. Funding is often subject to discretionary measures based on public policy and opinion, the mission of a foundation, or the interests of a private donor. This is another area of expertise in which universities and museums house many experts. A university often has the added bonus of an academic program on politics and government, federal and state government lobbyists, and alumni advocates all of whom can be powerful allies and resources for a museum. Of course, the national 
environment also has to be supportive of the concept and find value in its educational institutions.

While "producing an exhibition of history compresses time and space," technology compounds that compression making museum exhibitions and education very fast moving and multi-faceted targets. ${ }^{14}$ Technology has assisted with the expansion of the role of museums beyond curating artifacts and preserving history. It has enabled the accommodation of different learning styles; bridged the gap to appeal to patrons of multiple generations, educational levels and languages; and encompassed a wider audience by inviting access to the museum's holdings from beyond the edges of its physical foundation. The same is true of universities and the wealth of knowledge expressed throughout its communities. Technology not only allows for greater access and increased opportunities for the presentation of exhibits; the collections themselves are available for new and novel fields of research especially if a collection has been digitalized so that one can view it in a virtual platform. Technological advances allow scientists to expand their research into broader and unrealized sources of specimens. The use of biological collections for research has increased dramatically in the past three decades. As demonstrated in Table 1 (page 17), from an article published about the value of collections in research, the number of published articles utilizing specimens to address ecological issues began an upward trend in the 1980's. ${ }^{15}$ Another piece of research on the value of collections cited specific research efforts which utilized collections to demonstrate species decline. The authors began their article quoting Joseph Grinnell,

\footnotetext{
${ }^{14}$ Yakel, "Museums, Management, Media, and Memory," 290.

${ }^{15}$ Graham H. Pyke and Paul R. Ehrlich, "Biological Collections and Ecological/Environmental Research: A Review, Some Observations and a Look to the Future,” Biological Reviews 85 (2009): 249.
} 
Table 1: Number of Published Articles Using Biological Collections

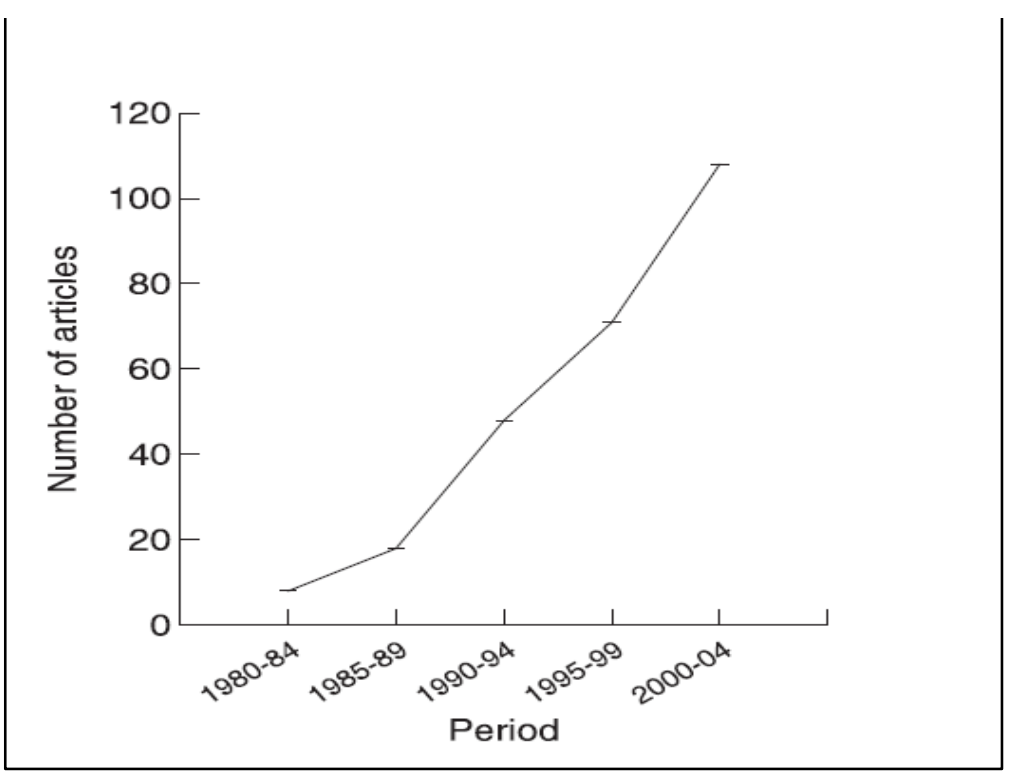

Source: Graham H. Pyke and Paul R. Ehrlich, "Biological Collections and Ecological/Environmental Research: A Review, Some Observations and a Look to the Future," Biological Reviews 85 (2009): 249

Note: Numbers, per five-year period, of published articles using biological collections to address ecological issues.

creator of the Natural History Museum at the University of California, Berkeley. Mr. Grinnell, a contemporary of Major Powell, stated in 1910 that his museum's potential, "will not, however, be realized until the lapse of many years, possibly a century... the student of the future will have access to the original record of faunal conditions."16 An example of the type of research that is being conducted using historical biological collections is the study of bird feathers for toxicity levels, particularly for heavy metals. In July of 2007, Dr. Jerald J. Dosch published an article outlining his testing of loon feathers for metal toxicity. The collection of loons, gathered throughout Minnesota from 1898 to 1902, is available in the University of Minnesota's Bell Museum

\footnotetext{
${ }^{16}$ Bradley H. Shaffer, Robert N. Fisher, and Carlos Davidson, "The Role of Natural History Collections in Documenting Species Declines." Trends in Ecology and Evolution 13, no. 1 (1998): 27.
} 
of Natural History. ${ }^{17}$ Similar research has been conducted to evaluate the impact of remnants of hunting shot on waterfowl, and the use of Alkyl Mercury in agriculture. As a result of this type of research, which provides a timeline of toxicity levels and mortality rates correlated against usage events (such as the use of lead shot for hunting or Alkyl Mercury in agriculture), regulations have been implemented to limit or ban causal substances. ${ }^{18}$

The prominence held by three of the founders and curators of the Illinois State University collections (John Wesley Powell, George A. Vasey and Stephen A. Forbes), allowed the ISNH museum to gain national renown and advance the institution's reputation as well as that of its faculty. The University continues to utilize its historical connections to these men, and by virtue of their work the institution continues to benefit from a collection that has only increased in value over the course of 150 years.

Illinois State University's Department of Biological Sciences houses The Vasey Herbarium, which contains over 50,000 specimens, and the John Wesley Powell \& Dale Birkenholz Natural History Collections, which contain bird and mammal collections totaling over 6,000 specimens. Both of the collections date back to the mid 1800's and have specimens gathered by the collections' namesakes. Powell memorabilia and specimens he collected also contribute to the Geography-Geology collection in their

\footnotetext{
${ }^{17}$ Jerald J. Dosch, "On Dead Birds' Tales: Museum Specimen Feathers as Historical Archives of Environmental Pollutants,” Environmental History 12 (July 2007): 663.

${ }^{18}$ Multiple research efforts consistently demonstrate the levels of mercury in birds before and after the ban on Alkyl Mercury in Sweden. Similar research efforts in the United States proved that lead shot was directly responsible for massive mortality events in water fowl populations. Reference W. Berg et al., "Mercury Content in Feathers of Swedish Birds from the Past 100 Years," Oikos 17 (1966): 71-83; T. Westermark, T. Odsjo, and A.G. Hohnels, "Mercury Content in Bird Feathers Before and After Swedish Ban on Alkyl Mercury in Agriculture," Ambio 4 (1975): 87-92; Glen C. Sanderson and Frank C. Bellrose, "A Review of the Problem of Lead Poisoning in Waterfowl," Special Publication Number 4, Champaign, Illinois: Natural History Survey (1986); Joanna Burger et al., "Heavy Metal Concentrations in Feathers of Common Loons (Gavia immer) in the Northeastern United States and Age Differences in Mercury Levels," Environmental Monitoring and Assessment 30 (1994): 1-7.
} 
Learning Resource Center, which is housed in a museum-like display room in the Felmley Hall of Science. Various uncatalogued items are distributed throughout campus and in private collections in the community. Whether purposed as museum objects or research objects, the natural history collection is an invaluable and under-utilized resource to the institution. An understanding of their history can inform their untapped potential. 


\section{CHAPTER II}

\section{THE FORMATION OF THE NATURAL HISTORY COLLECTION}

This chapter offers a history of the first fifty years of the natural history collection and assesses its significance in light of the expansionism of a growing nation. It will provide a brief biography of the central scientists involved in the collection and their influence in its development. A review of the transactions of the Illinois Natural History Museum and the proceedings of the Board of Education of the State of Illinois shows that the primary driver of the nation's scientific exploration was the economics of expansion. The museum collections were the result of political intent to catalogue the availability of natural capital.

Illinois State University is in an advantageous position to have numerous biological, geological, and botanical collections that were collected and curated by some of the most influential and renowned scientists of the mid-nineteenth century. Scientists and educators like John Wesley Powell, ${ }^{19}$ Stephen A. Forbes ${ }^{20}$ and George S. Vasey ${ }^{21}$

\footnotetext{
${ }^{19}$ John Wesley Powell was a U.S. soldier in the Civil War, geologist, explorer, professor at Illinois Wesleyan University and Illinois State University, and director of major scientific and cultural institutions including the Smithsonian Institution and the U.S Geological Survey. He is famous for two explorations of the west, including being the first surveyor of the Grand Canyon via the Green and Colorado Rivers. He is renowned for his development of land-use policies as well as his anthropological work with the indigenous people of the west. A well-researched biography of Major Powell is Donald Worster's A River Running West: The Life of John Wesley Powell (Oxford: Oxford University Press, 2001).

${ }^{20}$ Stephen A. Forbes was a professor at Illinois State Normal University and one of the more prominent curators of the INHS Museum. He is responsible for its conversion from a museum to a laboratory, and its consequent move to the University of Illinois where its role and research interests continue to thrive in the twenty-first century. Dr. Forbes is one of the first scientists to directly document human impacts on ecosystem viability, and his work with waterways and fish continues to be cited as landmark research. A comprehensive biography, as well as an overview of his research, was compiled by Robert Lovely for his doctoral dissertation, "Mastering Nature's Harmony: Stephen Forbes and the Roots of American Ecology." $\mathrm{PhD}$ diss., University of Wisconsin, Madison, 1995.
} 
believed in building an educated citizenry with a sound foundational understanding of the environment and how humans interact with it. The collections provided the institution with an environmental legacy and contributed to progressive educational ideas such Nature Study, which moved students from the classroom into the environment for experiential learning. Massive private collections of local, regional, and exotic specimens were gathered by practicing amateurs and scientists. They were given larger purpose when the Illinois Natural History Society was established, and its charter, identified in Section 2 of the incorporation articles for the Illinois Natural History Society reads:

Sec. 2. The object and purpose of said society shall be to conduct and complete a scientific survey of the State of Illinois in all the departments of natural history, and to establish a museum of natural history at the State Normal University, comprising every species of plants, insects, quadrupeds, birds, fishes, shells, minerals and fossils, within our State limits, as far as can be obtained, comprising also such other collections of natural history, from various parts of the world, as may be deemed necessary by said society. ${ }^{22}$

The survey had broad scope to identify and catalogue every living organism and mineral in Illinois from grass, to spider, to fish, to rock, to birds and larger mammals. The work was formed and organized in a series of commissions, committees made up of the founders and members of the Society, each group responsible for a designated area of study.

\footnotetext{
${ }^{21}$ Dr. George S. Vasey was a physician and an avid botanist. He contributed to the collections by providing specimens as well as serving as interim curator of the collection for a brief period after Powell left ISNU and before Forbes was officially named curator in 1872. Dr. Vasey was appointed to the Department of Agriculture as a botanist in April of 1872 and served the next two decades at that post in Washington D.C. He is credited for providing significant numbers of specimens at herbaria throughout the United States including the Smithsonian Institution. Illinois State University retains over 5,000 of the specimens that he collected in the herbarium which is named after him, the Vasey Herbarium.

22 "Transactions of the Natural History Society: For the Year 1860," ed. C. D. Wilber, Secretary (Springfield, IL: Bailhache \& Baker, Printers, 1861) p 5.
} 


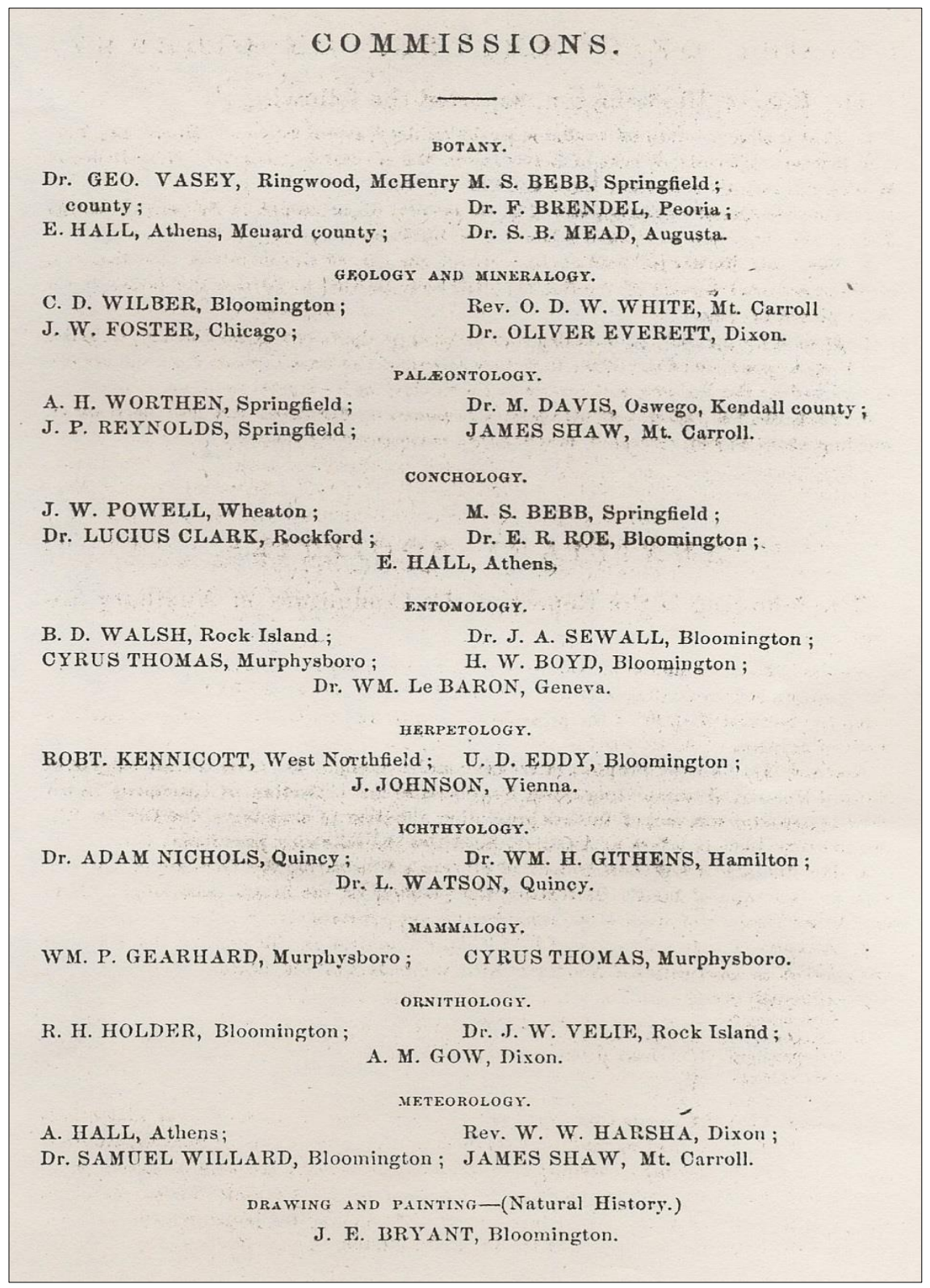

Figure 3: Commissions of the INHS. The committee assignments of the Illinois Natural History Society in 1860 . Each commission was responsible for the oversight of collections, literature, and reference materials related to their area of expertise. Transactions of the Natural History Society, June 27, 1860. Courtesy of the Hathi Trust Digital Library, accessed August 16, 2014, http://babel.hathitrust.org/cgi/pt?id=hvd.32044106211964;view=1 up;seq=9.

As can be seen in Figure 3, the commissions were comprised of eleven disciplines and members were divided among them according to their area of expertise or interest. "J. 
W. Powell" served on the Conchology Commission. Conchology, the study of mollusk shells, was a favorite interest of Powell's, and one of his primary pastimes was collecting them. It was noted that he collected several boxes during his service in the Civil War. Powell's conchology collection notes are the one book of his that remains at the Illinois State University archives. Members of the original committees often continued to play a significant role in the museum. For instance Cyrus Thomas served on both the Entomology and the Mammalogy Commission, and was appointed as one of the earlier curators of the INHS collections. These committees were formed at a time when scientific disciplines were developing as a more methodological and specialized approach to surveying the natural environment. They were comprised largely of men of elite status, who valued knowledge and who were premiere collectors as well as civic leaders. The networks that they maintained helped to grow the size of the collection through donations of existing specimens, as well as through the active procurement of new specimens.

When the museum was formed there were over 60,000 specimens contributed in the first two years, all under one roof, maintained by one curator. ${ }^{23}$ The spirit of the early scientists and their need to catalogue the world around them in an attempt to understand it has inadvertently provided the world with an invaluable vault of hidden information. The specimens in the ISNH collection were largely gathered in Illinois, but as per the

\footnotetext{
23 "Transactions of the Natural History Society: For the Year 1860, "Natural History in Schools" Read before the Illinois State Teacher's Association, at Quincy, December 25, 1860 by A. M. Gow, of Dixon, Illinois," ed. C. D. Wilber, Secretary (Springfield, IL: Bailhache \& Baker, Printers, 1861) p 87, accessed August 14, 2014, http://babel.hathitrust.org/cgi/pt?id=hvd.32044106211964;view=1up;seq=107.
} 
organization's legislative charter, global specimens were also obtained for the museum and made available for educational purposes.

The surveys that were undertaken at the state and national levels in the mid1800 's were a result of the United States' growing need for expansion. The purposes of the surveys were to identify potential resources for economic growth, and to determine the capacity to support that growth. In 1860 the Illinois legislative committee that was responsible for the formation of the Illinois Natural History Society proclaimed three resolutions that demonstrate this focus,

Resolved, That the Natural History of the country is of sufficient importance to all interests to warrant every effort on the part of educationists, everywhere, to promote its more general study, and the diffusion of a knowledge of it.

Resolved, That the work of the Illinois Natural History Society is so far identical with the industrial interests of the State as to render it not only politic but imperative that the Executive Committee of this Society adopt measures to secure their further co-operation.

Resolved, That a scientific survey of the State, in all the departments of Natural History, for the purpose of securing a more general knowledge of its agricultural and mineral resources, is a matter of vital importance to the people of Illinois, and worthy legislative action in furnishing means to do it economically and successfully. ${ }^{24}$

At the national level, the Commissioner of the General Land Office had noted in 1866 that the nation's industries were "making radical demands on the Nation's natural resources," and that "the proper development of the geological characteristics and mineral wealth of the country was a matter of the highest concern to the American

\footnotetext{
24 "Transactions of the Illinois State Agricultural Society, With Notices and Proceedings of County Societies, and Kindred Association," ed. John P. Reynolds. Volume IV - 1859-1860, (Springfield: Bailhache \& Baker, Printers, 1861), p 541. Resolutions 1, 5 and 6 are noted.
} 
people. ${ }^{25}$ As a result, four western surveys were approved by Congress on March 2, 1867 and Major Powell, a 35 year old, one-armed professor led one of them.

In this era of expansion and exploration, both the acquisition of land and the pursuit of knowledge drove the development of several scientific pursuits. Collecting and cataloging the natural world evolved from an amateur hobby to a professional responsibility. ${ }^{26}$ The director of the U.S. Geological Survey in 1880, Clarence King, assigned the surveys the responsibility of bringing science, particularly geologic science, to the forefront of national endeavors. He stated, that "Eighteen sixty-seven marks, in the history of national geological work, a turning point, when the science ceased to be dragged in the dust of rapid exploration and took a commanding position in the professional work of the country."27

The United States government's expansion of its control of territory in the West resulted in both the acquisition of resources and encompassing the indigenous populations that relied on those resources. This acquisition of capital and people presented "rich fields for research particularly in the line of natural history." 28 The convergence of intellectualism and untapped wealth set off a flurry of collecting, cataloguing, mapping and analyzing. The growing role of education and the establishment of public school systems leveraged, and in many cases fed into, this trend. This era provided the foundation for many collections at universities, including the Illinois Museum of Natural History established at the State Normal College in 1858.

\footnotetext{
25 "The Four Great Surveys of the West," United States Geological Survey, accessed September 6, 2014, http://pubs.usgs.gov/circ/c1050/surveys.htm.

${ }^{26}$ Elizabeth B. Keeney, The Botanizers: Amateur Scientists in Nineteenth-Century America (Chapel Hill: The University of North Carolina Press, 1992), 97.

27 “The Four Great Surveys of the West," United States Geological Survey, accessed September 6, 2014, http://pubs.usgs.gov/circ/c1050/surveys.htm.

${ }^{28}$ Conn, Museums and American Intellectual Life, 1876-1926, 34.
} 
The advancement of scientific methods, and the creation one hundred years earlier of a taxonomic classification system by Swedish scientist Carl Linnaeus, brought a level of professionalism, credibility, and specialization to collecting biological specimens, artifacts, and even languages. ${ }^{29}$ The surveys incorporated all of these, and a key figure in the exploration and assessment of the newly acquired territories was John Wesley Powell. Powell's career track began in teaching and eventually led him to a leadership position at the Smithsonian Institution. Much like his survey of the Grand Canyon, his career was an unchartered exploration winding through adversity and triumph. It is also fitting that Powell was a co-founder of the National Geographic Society, an endeavor wholly suited to the rugged intellectual. ${ }^{30}$ In addition to his many national accomplishments and contributions, Powell's endeavors benefited central Illinois, particularly the two institutions that lay claim to him as a former faculty member.

While his work on land use policy and the documentation of native languages may not be well remembered and are no longer referenced in the classrooms on either campus, he left a physical reminder of his contributions in the form of multiple collections of specimens and artifacts. Powell is most often credited for the extensive and diverse collections of the original museum however, the thousands of specimens that were gathered and donated are the result of the efforts of many men (and a few women) and their pursuits, as is evidenced by the 60,000 specimens that comprised the museum collections prior to Powell's renowned explorations. This collaborative effort of early

\footnotetext{
${ }^{29}$ Keeney, The Botanizers, 30.

${ }^{30}$ Donald Worster, A River Running West: The Life of John Wesley Powell (Oxford: Oxford University Press, 2001), 440.
} 
scholars enabled the preservation of over a century and a half's worth of natural history from the mid-west and around the globe.

These collections were a core component of Illinois State Normal University (ISNU) at the institution's founding in 1857. They comprised an entire floor of the campus' first and only building, Old Main. ${ }^{31}$ Since that preeminent founding, the collections have grown, shrunk, disappeared, been dispersed to other institutions, stuffed in closets, destroyed, horded, and periodically revered as a rediscovered treasure. Powell spent his life delving into the complex relationships between public policy, education and the environment, and it is befitting his efforts that those systems can continue to be examined by analyzing the various biological collections that he contributed to and

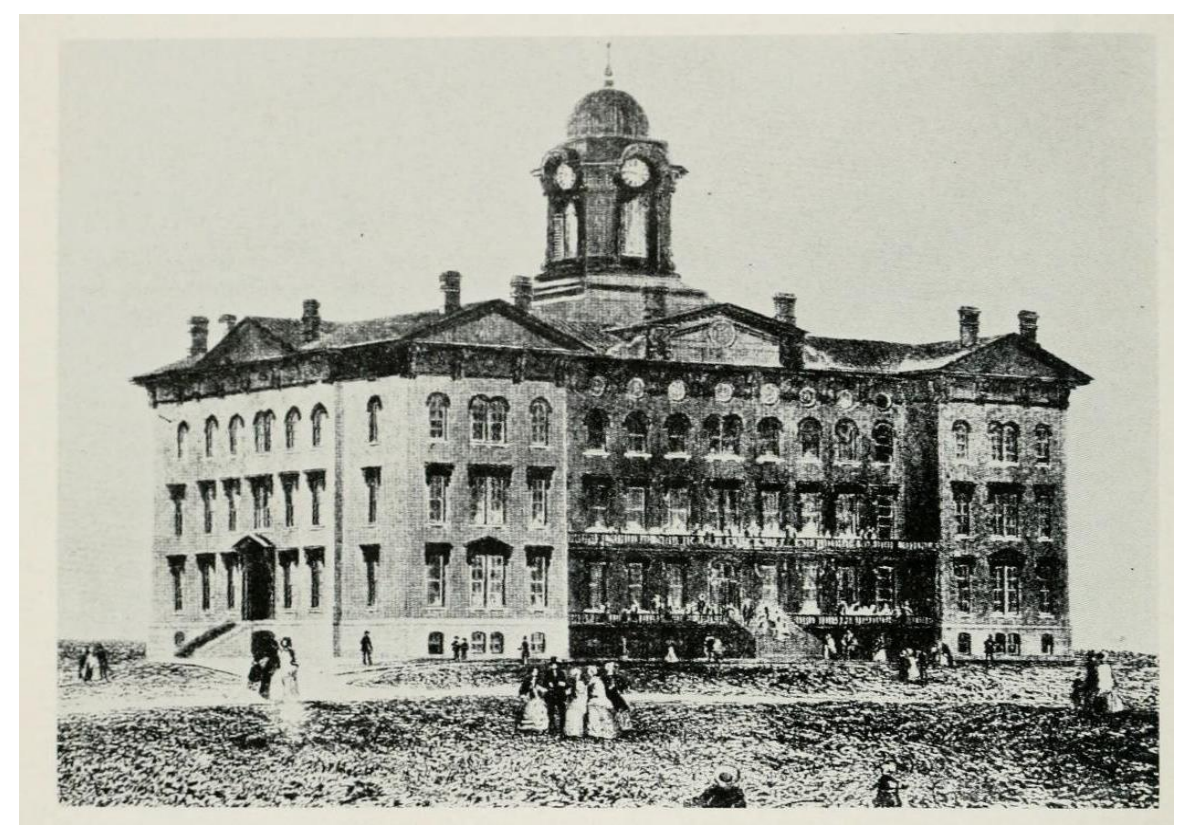

Figure 4: Photo of Old Main Building. The original campus building which housed the museum and laboratory until 1898. Photo courtesy of the Dr. Jo Ann Rayfield Archives at Illinois State University.

\footnotetext{
31 "On the fourth floor, halls for the literary societies, the art gallery and museum of natural history, each 32ft.x48ft., and a lecture hall 65ft.x75ft." Semi-Centennial History of the Illinois State Normal University, 1857-1907, page 34 .
} 
valued so dearly.

Notes from the transaction of the annual meeting of the Illinois Natural History Society (INHS) in 1860 discussed the current state of the collection, highlighting the lack of a physical space to house the display while optimistically noting that the State Normal School had agreed to provide museum space. The minutes explain that "In a few years, the collection of specimens thus made, constantly enlarging, will be a source of just pride to the citizens of Illinois." ${ }^{, 32}$ At that meeting, the Superintendent of the INHS, C.D. Wilbur, announced his resignation for personal reasons and nominated the Society's Secretary, John Wesley Powell, as his replacement. Powell agreed to take over the work however, his involvement with the Society, and later as curator of the museum, were peripheral during his appointments as he spent his time predominantly in explorations of the west or serving various roles in Washington, D. C. Some of his contemporary colleagues lamented the state of disrepair that his absence, and consequent neglect of his duties, had caused. ${ }^{33}$

John Wesley Powell was without a doubt one of the more prominent characters in scientific and political circles in the mid to late 1800 's, and he was the man most often affiliated with the Illinois Natural History Society. A man of stature and bearing, and described as having a quirky nature, his explorations afforded him prestige and some degree of celebrity status. Even a century after his death, there is an allure of Powell's exploits as a legendary explorer. ${ }^{34}$ The Department of Geography-Geology affords a

\footnotetext{
32 “The Agricultural Convention: Annual meeting of the Illinois Natural History Society: And Commencement Exercises of the State Normal University (1860)," Chicago, The Society, 6.

${ }^{33}$ Robert Allyn Lovely, "Mastering Nature's Harmony: Stephen Forbes and the Roots of American Ecology” (PhD diss,.University of Wisconsin, Madison, 1995), 48.

${ }^{34}$ Worster, A River Running West, 403-404.
} 
prominent place to Powell in the history of their academic program as well as their collections, citing on its web page "Without question, John Wesley Powell is the most widely recognized person associated with the Department... but after his departure eightyseven years elapsed until the Department hired its next academic geologist, Tom Searight in 1959."35 The Department of Biological Sciences leverages Powell's name on the collection and continues to utilize his work in research endeavors across multiple disciplines. Beyond the collections, Powell's contributions to the institution were actually very limited. He taught but one class at ISNU during the 1867-68 academic year while the rest of his time was devoted to the museum and acquiring funds for a collecting expedition on which he departed that summer. ${ }^{36}$ His brief affiliation continues to provide a level of credibility and historical legitimacy to the institution. Yet there were numerous criticisms of Powell, largely related to how he used his position to obtain funds and resources to further his own interests. And it is no small irony that in 1857, at the time that Powell was intent on furthering his formal education, he eschewed the newly formed Illinois State Normal University, and instead opted to attend the Illinois Institute (now known as Wheaton College). ${ }^{37}$

By 1858, Powell had "amassed a herbarium of several thousand plants, a large collection of shells, and a cabinet of reptiles." ${ }^{38}$ These varied collections became a component of the newly-announced museum that would be housed at the equally new State Normal University in Normal, Illinois, the doors of which had been opened just one

\footnotetext{
${ }^{35}$ Illinois State University Web-Site for Department of Geography-Geology, accessed August 24, 2014, http://geo.illinoisstate.edu/about/.

${ }^{36}$ Worster, A River Running West, 117.

${ }^{37}$ Worster, A River Running West, 73-74.

${ }^{38}$ Worster, A River Running West, 80.
} 
year earlier in 1857. A stated goal of the Natural History Society was to "collect information and specimens with reference to a thorough exploration of the state. ${ }^{\prime 39}$ There were many men involved in the formation of the society, men who would go on to make significant contributions to their fields of specialty as well as to the growing body of scientific knowledge and national policy related to the natural world. While donations of specimens were also provided by the founding members, the Natural History Society accepted collections from a variety of sources. In the July 1860 meeting notes, B.D. Walsh from Rock Island is recognized for his donation of a box of classified beetle specimens for the entomology exhibits and received accolades that he had "in the [course of that same] year named about 500 species of the insects of Illinois. ${ }^{, 40}$ In the same meeting the paleontologist Mr. McChesney of Springfield announced that he "had explored Illinois, and partially adjoining states, collecting specimens representative of the different geologic systems." As part of his report, he also said that he would "present to the Society" the duplicate specimens of his department. ${ }^{41}$ The Illinois Natural History Society's short lifespan (thirteen years) does not diminish the significance of its collections or the men who created, contributed to, and oversaw the organization. The Society created a foundation of natural science that continues its mission of education and exploration yet today. ${ }^{42}$

\footnotetext{
${ }^{39}$ William F. Steinbacher-Kemp, “The Illinois Natural History Society: 1858-1871” (Master's thesis, Illinois State University, 2000), 25.

${ }^{40}$ The Agricultural Convention: Second Annual meeting of the Illinois Natural History Society: And Commencement Exercises of the State Normal University (1860), Chicago, The Society, 8.

${ }^{41}$ The Agricultural Convention: Second Annual meeting of the Illinois Natural History Society: And Commencement Exercises of the State Normal University (1860), Chicago, The Society, 8.

${ }^{42}$ The Illinois Natural History Society evolved into the Illinois Natural History Survey which is currently operating out of the University of Illinois's Prairie Research Institute, accessed November 26, 2012, http://www.inhs.uiuc.edu/organization/.
} 
In 1860 Powell lobbied for additional funds to obtain more specimens for the collection, as well as a paid curator position, which even though some found it selfserving, also benefited the INHS and the museum. Powell's biographer, Donald Worster, notes; "The society, duly appreciative, immediately recommended him for the position and the salary."43 The criticism did not come until later. Powell's fund-raising methods and focus on expanding the scope of his collecting enterprise left a bad taste in some people's mouths. His fate was sealed when he took a significant portion of his contributions to the collection with him to the Smithsonian Institution years later. Despite the feelings of Illinois' institutional leaders, Powell became a leader in the natural history world.

In terms of his contributions to the Illinois Natural History Society and scientific culture, those hurt feelings and sense of betrayal have become a moot point. The passage of time has made his life's work more valuable and influential, and his detractor's concerns have been relegated to the archives, much like the specimens that he worked so hard to obtain. ${ }^{44}$ Illinois State University and Illinois Wesleyan University (IWU) did retain pieces of Powell's collections, although he took boxes of specimens with him to the Smithsonian Institution. ${ }^{45}$ In fairness to Powell, he had been collecting since he was a boy and it was his life's work and passion. The collection of invertebrates that graced the Illinois Natural History Museum had been partially obtained during his service in the Civil War (where he lost an arm in the battle of Shiloh). ${ }^{46}$ The tenacity and dogged determination of the man added to his rugged mystique. Major John Wesley Powell was

\footnotetext{
${ }^{43}$ Worster, A River Running West, 116.

${ }^{44}$ Steinbacher-Kemp, “The Illinois Natural History Society: 1858-1871," 53.

${ }^{45}$ Lovely, "Mastering Nature's Harmony: Stephen Forbes and the Roots of American Ecology," 48.

${ }^{46}$ Worster, A River Running West, 94.
} 
a scientist, scholar, explorer, politician, soldier, and teacher. His celebrity is not undeserved, and it inherently adds value to the items he collected and the entities he contributed to - no matter how large or small the contribution is perceived. Due to the inherent nature of people wanting to own a piece of history, or a piece of fame, specimens and artifacts of the collections have gradually disappeared from the institutions and found their way into private collections.

Through the course of time and loss of institutional memory, many of the pieces were dispersed throughout campus, resulting in their significance and provenance being temporarily lost. There are also other private holdings of Powell's pieces in the community. For instance the David Davis Mansion and Historical Site showcases two original photographic plates from the 1869 and 1871 surveys of the Green and Colorado Rivers. ${ }^{47}$ The separation of individual pieces from the collection has diminished what information the collection can provide as a whole. A single bird or prairie plant can provide a lot of information, but to see the bird in a photograph that has a date, visible weather conditions, and a location that can be pinpointed with exact geographic indicators, makes that specimen far more valuable. The wonderful thing about cataloguing the collection in 2015 is that much of it can be done digitally. No area would have to relinquish their treasures for the collection to regain its full research value, and the information can be added to the repository of global ecological system research, which reaches well beyond the well-appointed sitting room of the David Davis mansion.

Like many public figures Powell had both followers and detractors, which contributed to a situation where multiple people and institutions lay claim to his history

\footnotetext{
${ }^{47}$ David Davis mansion tour, Bloomington, IL. Guided by Dr. Marcia Young, Tuesday, October 30, 2012.
} 
and success. Illinois State University and Illinois Wesleyan University each have pieces and specimens that were collected during Powell's survey expeditions in the West, his time spent in Illinois and from neighboring states. Both universities also cite Powell's faculty appointments as part of their history, and they provided financial backing and resources for the expeditions that fundamentally launched his career. Ironically, even within an institution there is some degree of territorialism with regard to Powell's legacy. For example, at Illinois State University, both the Department of Biological Sciences and the Department of Geography-Geology lay claim to the man's legacy and degree of influence within their fields. Both also have collections that bear his name and showcase specimens that are directly attributable to him, but it was not Powell that built the collection to its pinnacle. The curators who followed Powell did the bulk of the work, but rarely get the credit they deserve. 


\section{CHAPTER III}

\section{CURATORS AND COLLECTORS: THE MEN WHO}

\section{REALLY MADE THE COLLECTION}

The expansion and organization of the museum after Powell's tenure will be covered in this chapter by highlighting two of the most influential collectors and curators, George S. Vasey and Stephen A. Forbes. The collections were initially legislated to produce an inventory of the resources available to a growing nation, and as curators of the collection all three men (Powell, Vasey and Forbes) had a great deal of knowledge about those resources. The initial surveys and cataloging of specimens was followed by the development of public policy on how best to address the economic potential. Powell was the first to make it to Washington D.C. and was an engaged party to those conversations on policy, but Vasey and Forbes were also influential in informing lawmakers on the politics of land and resource use.

John Wesley Powell's individual contributions to the collection were diverse and included everything from black bears, to clams, to pottery and languages. The surveys he led provided opportunities for other collectors with more targeted areas of interest. Some of the participants of the exploratory surveys returned to central Illinois with their collections, and those became part of the museum and research enterprise that was core to the mission of the ISNU. Yet, Powell's prominence as a figure in his own right does not 
correlate with significant contributions to the advancement of the museum. Rather, it took strong-willed and intelligent men to further the initiative which Powell had left in a sorry state. These scholars leveraged the collection and research for broader national policy initiatives, and ultimately moved ISNU's influential natural history research center to a land-grant institution south of ISNU. This initiated a century of turmoil for the remnants of the museum, but did not negate their value to the discourse on the economic viability of untapped resources.

The value of the University's collections for educational purposes has fluctuated over the course of the past century and a half and has been difficult to quantify in terms of a consistent metric. Dollar figures and specimen counts were indicators of success early in the collections' history. An 1870 accounting of the collections valued the entire inventory at $\$ 95,000$ and listed over 100,000 specimens in the botanical collection alone. The plant specimens comprised over one-quarter of the value of the entire collection with an approximate worth of $\$ 25,000 .^{48}$ The educational value was as intangible and immeasurable then as it is today. Reverting to the monetary assignment of worth for today's value makes some of the specimens priceless and irreplaceable. There is also hidden value in the specimens, such as undiscovered historical information accessed through new technology, much like an archaeologist opening a tomb and discovering room after hidden room filled with treasure. Specimens that had been common at the time of the collection may now be extinct, or the ecosystem has changed so drastically that they can no longer survive in the area where they were collected. It is due to the work of the collectors and curators over centuries that this historical environmental

\footnotetext{
${ }^{48}$ Charles A. Harper, Development of the Teacher's College in the United States (Bloomington, IL: McKnight \& McKnight, 1935), 363-364.
} 
information is now available. The relevance of the specimens has taken on a broader scope, and a greater importance, and the competency of the collector is just as important as the specimen he collected. ${ }^{49}$ For example, in ecosystem restorations it is imperative to know what plants, insects and soils are native. They are the foundation of the ecosystem, and the Illinois Museum of Natural History and ISNU was fortunate to have as preeminent a botanist as they did an explorer, Dr. George Vasey. Namesake of the Vasey Herbarium Collection housed at ISU in the Felmley Hall of Science and curated by Dr. Joe Armstrong.

Although a medical doctor by training, Vasey was an avid proponent of the field of botany as well as a collector. A founder of the Illinois Natural History Society (INHS), and a curator of the collections, Vasey became a prominent figure in the field of botanical sciences. In 1872 he was appointed as the United States Department of Agriculture's (USDA) first chief botanist, as well as the curator for the National Herbarium at the Smithsonian Institution. ${ }^{50}$ He held both positions until his death in 1893. ${ }^{51}$ Dr. Vasey specialized in grasses, particularly prairie grasses. The thousands of specimens he collected, as well as his observations and research, continue to maintain their relevance a century and a half later. Although his direct affiliations with ISNU and the IMNH were limited to four years (1868-1872), his influence and legacy are timeless

\footnotetext{
${ }^{49}$ Kevin Winkler, "Natural History Museums in a Postbiodiversity Era," BioScience 54, no.5 (2004): 457. The author summarizes the value of natural history collections and cites areas where they have demonstrated value in research on "... sentinel species, resiliency, baseline rates of disease incidence and genetic diversity among wild hosts, organismal distributions in relation to development and disturbance, emerging infectious diseases, genetic diversity in managed populations, food web changes, contaminants, biological responses to climate change, the fields of genomics and proteomics, and even bioterrorism research."

${ }^{50}$ Wm. M. Canby and J. N. Rose, “George Vasey: A Biographical Sketch.” Botanical Gazette, (May 1893): 173

${ }^{51}$ United States National Arboretum website. http://www.usna.usda.gov/Education/Vasey.pdf 
contributions to the development of botanical sciences and environmental history. ${ }^{52}$ Dr. Vasey did not have the same national credentials as Powell, but he did have the same passion for exploration and joined the survey of the west in 1869. Tenacity was another difference that distinguished the doctor from the Major Vasey left the expedition early and was appointed to the position of interim curator of the IMNH, which he held until his USDA appointment in 1872. By the time Dr. Vasey had left Illinois, his contributions to the Illinois Museum of Natural History (IMNH) and subsequent herbarium were substantial.

In 1871 oversight and administration of the IMNH was transferred to the State Board of Education. The collection and circulation of specimens for educational materials became one of the legislated functions of the IMNH. The charter of ISNU in 1857 specifically provided that "natural science, including agricultural chemistry and animal and vegetable physiology" were required to be taught. ${ }^{53}$ The dovetailing of the IMNH resources with the Board of Education culminated in another legislative act regarding education, the Natural History Act. In 1872 Illinois passed "a law requiring the teaching of four branches of natural science in the public schools of the state and the examination in these subjects of all holders of teachers' certificates."54 The requirement for uniform teaching curricula and a common standard of knowledge for teachers placed the museum and the collectors in a wonderful position to spread the wealth of their collections and expertise throughout the state. To facilitate that pedagogy, specimens

\footnotetext{
${ }^{52}$ Semi-Centennial History of the ISNU, 1857-1907: Prepared Under Direction of a Committee of the Faculty. (1907): 63 \& 67. (Located in Special Collections at Illinois State University: LD2347.A7376)

${ }^{53}$ Harper, Development of The Teacher's College in the United States, 361.

${ }^{54}$ Semi-Centennial History of the ISNU, 1857-1907: Prepared Under Direction of a Committee of the Faculty. (1907): 67-68. (Located in Special Collections: LD2347.A7376)
} 
were distributed to schools to supply teachers with observable materials. ${ }^{55}$ A contributor to the INHS noted that the specimens allowed students to

See more clearly the force of descriptions given in their readers and geographies... break down narrowness of view and awaken enthusiasm and energy in studying the great book everywhere open before us. A bit of lava will be secured to give reality to the description of a volcano. An Indian pipe, hatchets, and arrow-heads will remind the little folks of the red man's history. ${ }^{56}$

The author stated that a student's enthusiasm for learning would increase and the lessons would be better comprehended because of the availability of a tangible example of what was being taught. The investment in education, combined with the ongoing and popular environmental surveys taking place around the country, placed the IMNH in an enviable position to gain financial resources and support, and bring its hosting institution a level of prestige and credibility. The legislation of these items also guaranteed a robust historical record for educating future generations. The specimens that were collected by Vasey, combined with his diligent notes and observations during collection, continue to educate students and have become core to professional practice in botanically related fields.

In a brief history of Dr. George Vasey, the author noted a reference in the book, "Plants of the Chicago Region (1999)," of a specimen collected by Vasey.

Agoseris cuspidata, PRAIRIE DANDELION. One of our very rarest plants. Known in our area only from McHenry County where it was collected by Vasey in a prairie at Ringwood on May $20,1858 .{ }^{57}$

Specimens hold multiple values: monetary, research, educational, and even a value related to the perceived worth of the person who collected it. While there is no

\footnotetext{
${ }^{55}$ Stephen A. Forbes, "History of the Former State Natural History Societies of Illinois," Science, New Series 26, No 678 (Dec. 27, 1907): 892.

${ }^{56}$ J. H. Blodgett, “Object Lessons," Transactions of the Illinois Natural History Society; For the Year 1860, 628.

${ }^{57}$ Ed Collins, "Searching for Doctor Vasey." Chicago Wilderness, Winter 2001, 1.
} 
indication in the article whether the species was common during the period that Vasey collected it, its limited natural occurrence one hundred and fifty years after it was collected increases the value not only of that particular Vasey specimen, but of the species in general. Understanding pre-existing populations and ecosystems plays a key role in species protection and land conservation. It bodes well for the native plants and animals to have a historical record of their existence which may afford them a level of security and longevity through public policy as legislators enact conservation and preservation laws.

Measuring the environmental changes from date of collection to current day presents researchers with information on a number of areas of study in conservation biology. For instance in the article about Dr. Vasey's influence and continued relevance the author writes,

The period from 1848 when Vasey arrived in Illinois until his relocation to Washington in 1866 holds the most relevance for restoration ecologists working in the Chicago region. His correspondence is rich in first-hand information relating the area's natural history. ${ }^{58}$

Further "the character and richness of the prairie is understood today as well as it was in Vasey's time. ${ }^{, 59}$ Also referenced is the terminology utilized in the 1800 's to describe various ecological systems from which specimens were gathered or identified. Vasey predominantly utilized "prairie" and "barren" to denote the habitats. Prairie is still universally understood, but a barren was a distinctive type of environment that fundamentally transitions from prairie to forest. An 1836 description in the "Illinois Gazetteer" was cited in the article:

\footnotetext{
${ }^{58}$ Collins, "Searching for Doctor Vasey," 3.

${ }^{59}$ Collins, "Searching for Doctor Vasey," 4.
} 
In the western dialect the term barrens has since received a very extensive application throughout the west... The timber in general scattering, of a rough and stunted appearance, interspersed with patches of hazle (sic) and brushwood. These barrens occur where the contest between fire and timber is kept up, each striving for the mastery.

The rapidity with which the young growth pushes itself forward, without a single effort on the part of man to accelerate it, and the readiness with which the prairie becomes converted into thickets, and the barrens into a

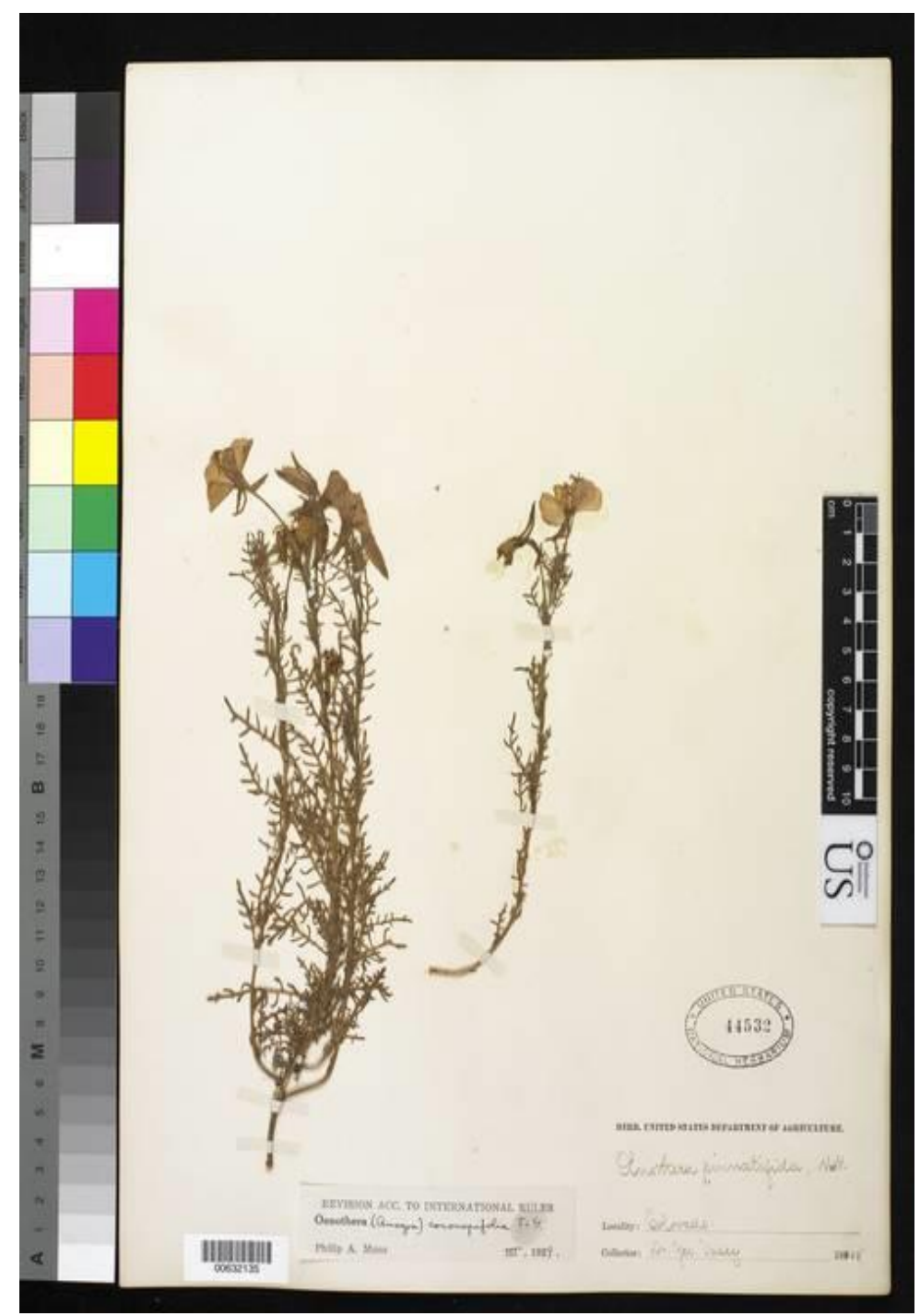

Figure 5: - Specimen collected by George S. Vasey. In collections at the Smithsonian Institution. http://collections.nmnh.si.edu/search/botany/ 
young forest, shows that in another generation, timber will not be wanting in any part of Illinois. ${ }^{60}$

Understanding the terminology of the collectors in any era allows researchers to place a specimen properly within a particular environment and to track the natural progression of changes in that environment against other influences. The private notes of collectors offer as much valuable information as the specimen itself. The research value of a specimen increases when it is accompanied by vivid descriptions, photographs, georeferencing information, and observations made prior to its collection. ${ }^{61}$

Illinois State University has utilized the herbarium collection, aptly named the Vasey Herbarium, for research and teaching since the original inception of the collection in 1857. The Department of Biological Sciences promotes the collection on its website, explaining:

The Vasey Herbarium houses some 50,000-60,000 specimens representing over 4500 species. The primary purpose of this collection is to support the educational and research function of the Department of Biological Sciences, but it also represents some of the earliest collections of plants in central Illinois, an important resource for conservation and restoration. The Herbarium also houses teaching collections of fungi, slime molds, fossils, economic botany specimens, and algae.

In addition to extensive collections of central Illinois prairies and woodlands dating to the middle 1800s, the Herbarium has many specimens collected from the mountains of western United States and California. The historically most important specimens were collected by George Vasey who accompanied John Wesley Powell on his geological expeditions exploring the Colorado Rocky Mountains (Lat. 40-41 N) area in 1868. These specimens represent the earliest scientific collections

\footnotetext{
${ }^{60}$ Collins, "Searching for Doctor Vasey, " 5.

${ }^{61}$ Pyke, "Biological Collections and Ecological/Environment Research, 250-251.
} 
from this area. The herbarium also contains exchange specimens from Europe dating back to the early 1800 s. $^{62}$

Vasey's lifelong efforts also established prominent research collections at herbariums throughout the country, including the National Arboretum. ${ }^{63}$ During Vasey's tenure at the Smithsonian he produced a collection of grasses of "nearly 15,000 sheets, a great many of which were mounted and named" by Vasey himself. ${ }^{64}$ The renowned botanist worked diligently to promote the field of botany and its usefulness in agriculture and public land use. For example, Vasey was instrumental in establishing the Grass Experimental Station at Garden City, Kansas. ${ }^{65}$ This research facility, developed for studying grasses in arid climates, was of particular interest in land development and expansion. One of the research projects he is credited with is his "idea to experiment with both native and introduced species for the purpose of obtaining grasses and forage plants adapted the region west of the $100^{\text {th }}$ meridian where irrigation is not practicable."66 Despite these contributions, Vasey's involvement in public policy as it relates to land use of the frontier is often overlooked by scientists who fought a political battle to persuade Congress that the lands west of the $100^{\text {th }}$ meridian "were wholly unsuitable for agriculture."67 Major Powell had also come to the same conclusion during his survey expeditions and his findings were published by the government in the 1878 "Report on

\footnotetext{
${ }^{62}$ Illinois State University, Department of Biological Sciences, accessed August 24, 2014, http://bio.illinoisstate.edu/jearmst/herbarium/isuherb.htm.

${ }^{63}$ San Juan College Herbarium, accessed August 24, 2014, http://www.sanjuancollege.edu/pages/425.asp. San Juan College boasts they have the largest herbarium in the Four Corners region and a portion of that is a Vasey collection.

${ }^{64}$ Canby, "Vasey: A Biographical Sketch," 174.

65 Smithsonian Institution Archives - George Vasey Papers, 1889-1893 (SIA RU007087) http://siarchives.si.edu/collections/siris_arc_217245

${ }^{66}$ Canby, "Vasey: A Biographical History," 175.

${ }^{67}$ George H. Daniels, Science in American Society: A Social History (New York: Alfred A. Knop, 1971), 186.
} 
the Lands of the Arid Region of the United States. " It is a monumental treatise on land management and clearly articulates the issues that must be addressed to settle the West, most notably water, prairie and forest management. Powell noted "Compared with the whole extent of these lands, but a very small fraction is immediately available for agriculture." He also stated that the engineering work necessary to redeem the land required highly skilled engineering experts and farmers would be unsuitable for the task due to the complexity and cost. ${ }^{68}$ The work has been described by twenty-first century contemporaries as "revolutionary regarding land and resource administration" and his "uncanny anticipation of the power struggle which has emerged between western farmers and ranchers and the federal government." ${ }^{, 99}$

The prospects and promise of the surveys demonstrated that there was a vastness to the West made up of untold resources, and most importantly, of space for a growing nation. Congress was eager for the land and the resources, and refused the advice of the countless agents and surveyors they had paid to assess the land. Congress was advised repeatedly that the land was not suitable for agrarian purposes without monumental engineering, and that the water must be protected and equitably distributed without causing harm to the hydronic systems and natural reservoirs. At one point, the head of the Federal Boundary Survey, Major William H. Emory, frustrated by the legislature's stubborn ignorance in the pursuit of expansion, suggested that the "whole legislation of Congress must be remodeled and reorganized. ${ }^{, 70}$ His wisdom with regard to re-

\footnotetext{
${ }^{68}$ J. W. Powell, "Report on the Lands of the Arid Region of the United States, With a More Detailed Account of the Lands of Utah; With Maps," 1878: preface. http://pubs.usgs.gov/unnumbered/70039240/report.pdf

69 "John Wesley Powell on the Role of Government in Land Management," University of Illinois. http://www.english.illinois.edu/maps/poets/m r r/merwin/jwpowell.htm

${ }^{70}$ Daniels, Science in American Society: A Social History, 186.
} 
engineering Congress did not prevail, and the elected body instead found a scientific report that provided the kind of data they needed to support their expansion efforts.

Dr. Vasey provided the research and reassurance that Congress needed through the research station and his study of hybrid grasses. In his 1886 "Report of an Investigation of the Grasses of the Arid Districts of Kansas, Nebraska, and Colorado," Vasey notes that the "capacity of the land cannot be realized under the ranche system." He goes on to suggest that if cattle ranges are restricted in order to allow for "cultivation of the land and pastures of more productive grasses, we may expect greatly increased population and wealth."71 While the expansion into the west had been in progress for most of the nineteenth century, the government's legislative control of the process grew more robust in the late 1880's in an effort to advance the economic interests of the nation. Oklahoma was opened to homesteaders in 1889 and 50,000 settlers claimed the 1.92 million acres of the state in one day. It would take over five decades to understand the environmental impacts of this expansion. This misguided policy move to encourage agrarian settlement of the West contributing to the Dust Bowl of the 1930's, which prolonged the economic recovery from the Great Depression, and caused the loss of topsoil and crop production capabilities on 135 million acres by 1934 . The federal government enacted several laws in this decade to counter the impacts of previous administrations' short-sighted legislation. ${ }^{72}$ The use of science, and scientists, to steer

\footnotetext{
${ }^{71}$ George S. Vasey. "Report of an Investigation of the Grasses of the Arid Districts of Kansas, Nebraska, and Colorado." Department of Agriculture Botanical Division, Bulletin No. 1 (Washington: Government Printing Office, 1886): 5-6. Quote includes spelling as written by Dr. Vasey.

72 “Timeline: Surviving the Dust Bowl, 1931-1939," PBS http://www.pbs.org/wgbh/americanexperience/features/timeline/dustbowl/
} 
and inform public policy placed several ISNU professors into the public realm at the state and national level.

Vasey and Powell both ended up in Washington D.C. influencing policy. They were colleagues at the Smithsonian Institution contributing to science, legislation and history. They influenced the role of science in higher education, and expanded the educational offerings of Illinois State Normal University. After their departures, the institution continued to have pioneering men furthering the educational mission and bringing renown to the quality of academic programming. Perhaps not as nationally recognized as Vasey and Powell, Stephen A. Forbes was an intellectual power house in his own right and is responsible for transforming the IMNH into a working laboratory, furnishing specimens for classroom use throughout the state, conducting pivotal work on comprehending ecosystems, and ultimately creating the Illinois Natural History Survey, which resulted in moving the bulk of the collections to the University of Illinois. Although not a beneficial move for ISNU, once again, the distance of time reveals Forbes's contributions, particularly in light of the impact he had made as a result of his far-sighted thinking. A tireless man, his ambitions to transform the application of science and education were transformed into action as early as his appointment to the museum in 1872.

Some insight into the efforts of Stephen A. Forbes' in maintaining the integrity of the collection is evident in a report he presented to the Board on June 25, 1873. Professor Forbes prominently noted that in the prior six months, "numerous additions have been made to the cabinets and library of our Museum of Natural History, the work of its thorough organization has been completed, and measures have been taken to increase its 
future value and efficiency as a means of popular education."73 This report reflects the expanded role that the museum played in public education by providing specimens to school systems throughout the state. It is also the culmination of a far-sighted resolution set forth by the State Board in 1866 "that every common school ought, at some day to have a Museum of Natural History; and that the object is worthy of consideration in the construction of school-houses."74

Duplicate specimens had been distributed to high schools throughout the state since the opening of the museum, but with the passing of the Natural History Act and the appointment of Forbes as curator, the process for providing specimens to schools became more efficient, organized, and purposeful. Forbes wasted no time and in the same year as his appointment, he enlisted Illinois school districts to assist with the collection and distribution of specimens throughout the state. His solicitation explained:

The recent introduction of the natural sciences into our common school course of study has developed a general demand for specimens in natural history which I am trying to supply. It is designed to furnish, in time, to every school in the state which will use and properly care for it, a small collection so selected as to illustrate in the best possible manner, the branches required to be taught. $^{75}$

Professor Forbes acknowledged his limited time and resources as an impediment to accomplishing this on his own, and requested assistance saying, "It will be an easy

\footnotetext{
${ }^{73}$ Illinois State Board of Education, "Proceedings of the Board of Education, State of Illinois, 1873" (1873), Regular Meeting Held at Normal June 25 \& 26, 1873 (University Publications, Paper 17). Available through the Dr. Jo Ann Rayfield Archives at Illinois State University, http://ir.library.illinoisstate.edu/univpubs/17.

${ }^{74}$ Illinois State Board of Education, "Proceedings of the Board of Education, State of Illinois, 1866" (1866), Regular Meeting Held at Normal December 19, 1866 (University Publications, Paper 58). Available through the Dr. Jo Ann Rayfield Archives at Illinois State University, http://ir.library.illinoisstate.edu/univpubs/58.

${ }^{75}$ Stephen A. Forbes, "To the Board of Education of the State of Illinois," Proceedings of the Board of Education of the State of Illinois; Regular Meeting Held at Normal, June $25^{\text {th }}$ and $26^{\text {th }}, 1873$. Printed by N. C. Nason, Peoria, IL: 17-19.
} 
matter, however, for the teachers and pupils of the state to collect and send to this museum, in one or two seasons, a sufficient number and variety of specimens liberally to supply our schools." Forbes named, arranged and redistributed the selections providing uniform and consistent appropriations of specimens ensuring continuity in teaching regimens. ${ }^{76}$ Eight years after Forbes had submitted his initial request for aid, fifty-four high schools had responded and "reported the teaching of zoology and the desirability of such collections."77 Professor Forbes's efforts had proved successful, and he had created a foundation of collections in educational systems throughout the state of Illinois.

Forbes is representative of the early scientists who began their careers as amateur collectors and adapted their methods and practices as the trend toward professionalism and credentialing evolved. This focus on science enabled the expansion of the museum and subsequent laboratory, but it also resulted in the dissolution of the museum's collections. $^{78}$ Forbes spent his initial years as curator organizing and displaying the specimens, obtaining resources for the museum, and promoting education of the natural sciences. ${ }^{79}$ Forbes's ecological research interests and his familiarity with the European influence of laboratory science led to the demise of the museum at ISNU. A research project examining the stomach contents of birds to determine avian impact on crops prompted Forbes to create more space for laboratory work, diminishing the space available for cases and displays of the previously gathered specimens.

\footnotetext{
${ }^{76}$ Semi-Centennial History of the ISNU, 1857-1907: Prepared Under Direction of a Committee of the Faculty. 1907: 69-70. (Located in Special Collections: LD2347.A7376)

77 "Thirteenth Biennial Report of Superintendent of Public Instruction of the State of Illinois," The Teacher's College, 370: 143-144.

${ }^{78}$ Steinbacher-Kemp, The Illinois Natural History Society, 141.

${ }^{79}$ Lovely, Mastering Nature’s Harmony, 62-64.
} 
Europe, particularly Germany, had embraced a form of teaching based on handson experimentation and visual learning. The laboratory revolution had created a place for the "exchange or transit point of discourses, concepts and recipes, where ideas and physical materials could be confronted with each other and combined in increasingly new ways. ${ }^{800}$ Forbes's familiarity and personal success with the methods transformed his teaching and research, and the relevancy of the museum specimens for his work. Forbes sought new specimens for dissection and physiological research specimens with stomach contents that could be analyzed under a microscope and organs that were not dried out or soaked in formaldehyde. It would be another century before the technology and knowledge needed to leverage the IMNH specimens would become available. Until then, they were just something to look at and they took up valuable space.

The renewed utilization of natural history collections as laboratory specimens is a by-product of the availability of new technology and the advancement of systems thinking as it relates to ecology. The ability to analyze features of the specimens that had never been available before has revolutionized their uses to science and informs our historical knowledge of agricultural practices, urban land use, and even climate change. Much like the new world of research that the microscope opened to early scientists, ${ }^{81}$ the advent of DNA cataloguing, GIS mapping, and measuring toxicity in the most minute of specimens has turned these former dust-collectors into sought-after research subjects. The secrets they hold are alluring, and their origins have become the stuff legends are

\footnotetext{
${ }^{80}$ Henning Schidgen, "The Laboratory," European History Online (Published: 2011-08-08) Chapter 3, Section 18. Accessed, September 7, 2014. http://ieg-ego.eu/en/threads/crossroads/knowledgespaces/henning-schmidgen-laboratory\#TheLaboratoryRevolutionofthe19thCentury.

${ }^{81}$ Proceedings of the Board of Education of the State of Illinois: Regular Meeting Held at Normal, Dec. 9, 1885. M. L. Seymour, Teacher of Natural Science stated in a letter to President E. C. Hewett that "There are eight compound microscopes and an abundance of material for microscopic work." In that same letter he notes the "work in botany and physiology has been transferred to the museum." Young papers.
} 
made of. Kristofer Helgen, a mammalogist at the Smithsonian's National Museum of Natural History, in discussing the current efforts to discover and catalogue species, "notes that two out of three new mammal species are discovered in museum collection cabinets. ${ }^{.82}$

A broader analysis of natural history and the history of science can be gained by utilizing a recently developed interdisciplinary approach to human and natural systems, Coupled Human and Natural Systems (CHANS). This framework is an inter-disciplinary approach to the analysis of humans and ecology. It reveals "new and complex patterns and processes not evident when studied by social or natural scientists separately." ${ }^{93}$ It extends scholarly analysis "well beyond what was commonplace in ecological and social sciences research just a decade or two ago." ${ }^{84}$ A study of six different sites from five continents utilizing the CHANS analysis reveals that factors such as time, resiliency, government, and socio-economics play key roles in systems, but do not necessarily translate uniformly across sites. The complexity of systems is such that there is not a single solution for the same type of issue. The limited biodiversity of the grizzly bear in Yellowstone National Park will likely require a different solution than the same level of threat to the biodiversity of giant pandas in Wolong, China. A finding relevant to natural historical collections is that "Coupled human-natural systems are not static; they change over time. Although the human population sizes have increased in all six study sites over

\footnotetext{
${ }^{82}$ Richard Conniff, "Meet the Species," Smithsonian, July/August, 2010: 52.

${ }^{83}$ Jianguo Liu, Thomas Dietz, Stephen R. Carpenter, Marina Alberti, Carl Folke, Emilio Moran, Alice N. Pell, et al., "Complexity of Coupled Human and Natural Systems," Science 317, September 14 (2007): 1513.

${ }^{84}$ Jianguo Liu, Thomas Dietz, Stephen R. Carpenter, Carl Folke, Marina Alberti, Charles L. Redman, Stephen H. Schneider, et al., "Coupled Human and Natural Systems," AMBIO: A Journal of the Human Environment 36, no. 8 (2007): 639.
} 
the past several decades, the resultant ecological impacts have differed." ${ }^{, 85}$ The collections are needed to assist in identifying what the ecological impacts have been.

To put the framework into context it helps to understand how twenty-first century scientific approaches differ from those methods in practice at the time of the museum's inception. In the 1870's, the developing influence of science in the role of economics trumped static displays of dead animals. Forbes's research and position as the state's first economic entomologist, an appointment he accepted in 1882, aptly demonstrated this trend. As a result of this political shift, Forbes was able to garner legislative and university administrative support for laboratory space and applied biological research. ${ }^{86}$ The museum collections were subsequently compressed, and duplicate specimens dispersed, in order to accommodate laboratory research space.

Applying the CHANS framework to the study of environmental history, it becomes possible to see that Forbes was one of the first scientists to grasp the concepts of ecological connectedness in his research. He was fundamentally a pioneer of ecosystem research. Robert Allyn Lovely notes in his dissertation on Stephen Forbes that "his [Forbes's] foundation for the development of ecological thought," was derived from his early biological research which "prompted Forbes to think about how organisms and population groups interacted, a topic that had not received much scientific attention prior to his investigations." ${ }^{87}$ Forbes's research centered on food systems, such as how predator/prey interactions affected agriculture and how fish populations were impacted by water quality from industrial outputs. His innovative mapping of species by age, size

\footnotetext{
${ }^{85}$ Liu, "Complexity of Coupled Human and Natural Systems," 1516.

${ }^{86}$ Steinbacher-Kemp, The Illinois Natural History Society, 141.

${ }^{87}$ Lovely, Mastering Nature's Harmony, 355-356.
} 
and habitat enabled pivotal understandings of the growth cycles of fish and their prey, and provided research on aquatic ecosystems that continues to be referenced in twentyfirst century research. ${ }^{88}$ Forbes's progressive work and world view adjusted how he viewed the instruction of natural science and the role of the museum in the educational process. His work still largely focused on the interaction of the ecosystems as separate constructs, human interactions with those systems were not part of the scientific process. In 1877 Forbes requested that the Illinois State Board of Education allow the conversion of the museum into a laboratory and research center. He also promoted the centralization of specimens as resources for teachers throughout the state. He wrote:

The distinctive discipline of science can only be got by the immediate exercise of the mind upon objects and upon ideas directly derived from object. Materials for study, and named cabinets as the standards of reference, are the sine qua non of work worth doing. To incite and reward natural history work, nothing has been found more effective then skeleton cabinets of representative species... ${ }^{89}$

The Board approved the dissolution of the IMNH at Illinois State University and its conversion to the State Laboratory of Natural History (SLNH). The specimens and associated educational materials were directed to be "deposited, as soon as practicable, in the museum established by the act." 90 The new State Museum of Natural History was to be established in Springfield, Illinois, the state capital. In July 1878 Forbes presented his

\footnotetext{
${ }^{88}$ Lovely, Mastering Nature's Harmony, 357.

${ }^{89}$ Stephen A. Forbes, Annual Report to the Illinois State Board of Education: Circular of Information of the Illinois State Laboratory of Natural History, Normal, IL, (July 1878), 4. The Circular begins with Forbes' reading of this annual report to the State Board of Education. Available through the Dr. Jo Ann Rayfield Archives at Illinois State University, http://ir.library.illinoisstate.edu/univpubs/22.

${ }^{90}$ Annual Report to the Illinois State Board of Education: Circular of Information of the Illinois State Laboratory of Natural History, Normal, IL, (July 1878), 5. Available through the Dr. Jo Ann Rayfield Archives at Illinois State University, http://ir.library.illinoisstate.edu/univpubs/22.

Following Forbes' report, the proceedings of the meeting are presented in narrative fashion including the reference to the legislative act passed by the General Assembly to create a natural history museum at the "new State house in Springfield."
} 
annual report to the State Board of Education and outlined how the changes he proposed a year before had been completed or were in process. Specimens were removed from display, and the "last vestiges of the Illinois Natural History Society's once-glorious museum were gone." 91 Portions of collections were retained in the newly established laboratory, and they continued to be maintained by Forbes as he created a premiere research laboratory.

As further evidence of Forbes' progressive thinking, Lovely notes that the laboratory that Forbes created in the late 1870's was significantly ahead of its time, particularly for a Midwestern undergraduate institution. While Europe was leading the world in the development of laboratories, the United States was woefully behind. Hence, Professor Forbes's creation of a robust and well equipped laboratory at ISNU (a relatively new undergraduate institution) placed the university in a very favorable position. Ivy League schools such as Harvard did not begin to offer laboratory courses until $1882 .^{92}$

The specimens that remained were transformed from museum exhibits to research aids through a process in which they were "organized systematically - labeled, catalogued and indexed as scientific reference aids, without regard to their appearance and presentation as exhibits." 93 The fairly simple transition of a specimen from museum piece to laboratory aid demonstrates the divergent practices and thought processes regarding natural specimens and their role in education and research.

\footnotetext{
${ }^{91}$ Steinbacher-Kemp, The Illinois Natural History Society: 1858-1871, 142.

92 Lovely, Mastering Nature's Harmony, 83.

${ }^{93}$ Lovely, Mastering Nature's Harmony, 85.
} 
The collections transitioned through multiple purposes under Forbes's curation. They served as specimens for biological study, museum pieces, and portable travel aids for classroom programs. Just seven years after Forbes created the laboratory, the fate of the specimens was once again in question when the professor accepted a position at the University of Illinois in 1885 . Forbes accepted the opportunity while simultaneously orchestrating the merger and move of both the Office of State Entomologist and the Natural History Laboratory to relocate with him to the land grant institution. As a result of Forbes's efforts, the State Laboratory of Natural History was transferred to the University of Illinois along with a good portion of the collection however, not all of the specimens were dispersed to that institution, allowing the museum at the Normal School to continue. ${ }^{94}$ Although Forbes and his enterprises were now headquartered forty-five miles southeast of his former institution, he continued to oversee the laboratory collections as head of the state's Economic Entomology Department until his death in $1930 . .^{95}$

It is at that point that the history of the collections became fragmented, as did the laboratory collection itself. Simultaneously, on the national and international spectrum, there was a movement to teach natural science more methodically, as well to teach nature more holistically. The contrasting approaches, Nature-Study and New Botany, utilized radically different pedagogical methods. "New Botany stressed scientific thought and method in secondary and postsecondary education," while Nature-Study promoted experiential learning through interacting with and observing nature, and was largely

\footnotetext{
${ }^{94}$ Steinbacher-Kemp, The Illinois Natural History Society, 30.

${ }^{95}$ Steinbacher-Kemp, The Illinois Natural History Society, 145.
} 
advocated for elementary students in urban settings. ${ }^{96}$ The role of the specimens was once again going to change to meet the curricular needs of college students and to prepare teachers to teach the natural sciences.

In June 1885, the State Board of Education appointed M. L Seymour as curator of the Museum and Laboratory of Natural History. Note the change in the museum's name. This reflects a revisiting of the purpose of the collection, and Seymour elaborates on this in a letter to the Board. As he recounted in his letter, the Board "had urged the importance of connected work in elementary science for the direct benefit of the Normal students, especially to aid them in teaching science in the public schools." Seymour offers an example of how he accomplished this by bringing elementary children "in actual contact with mounted specimens of birds and mammals, as well as with living objects." 97 Seymour began to reestablish the museum collections that had once been a source of pride for the institution, and he utilized the collections for teaching the natural sciences in museum fashion and for laboratory research.

Forbes had provided laboratory space that enabled advanced scientific study at a time when many institutions lacked the funds and political resources to obtain microscopes, dissection tools and other affiliated research equipment. Further enhancing the scientific education program was Seymour's investment of time and energy into teaching elementary school students. As Elizabeth Keeney discusses in her book on the development of amateur hobbyist to professional, students and teachers were apt to find the study of natural sciences in a laboratory setting "overwhelmingly complex and

\footnotetext{
${ }^{96}$ Keeney, The Botanizers, 52.

97 "Proceedings of the Board of Education of the State of Illinois, Regular Meeting Held at Normal, June 24, 1885." M.L. Seymour's letter to the Board, 10. Young papers.
} 
boring." ${ }^{.98}$ Without a strong foundation in natural science studies, and a grounded connection gained through experiential learning, advanced laboratory resources were of little use and lacked practical application. Keeney says:

High school pupils of tender years were faced at the start with the compound microscope and preparations of minute micro-organisms and complex transverse sections unrelated to anything before heard of in the pupil's experience, and the connection, if there was any, with life interests of any sort was either overlooked purposefully omitted. The subjects frequently carried the incubus of long and unfamiliar Latin names. Lengthy and laborious laboratory exercises with the requirements of drawings which in the end showed little comprehension of the subject. ${ }^{99}$

Thus, portions of the laboratory space and specimens were once again transformed to serve as a museum, a function it served throughout Seymour's appointment and the appointment of Buel B. Colton who followed him. ${ }^{100}$ The role of the museum began to diminish as the concepts of Nature-Study gained momentum. Its emphasis on place-based study, which resulted in field trips and the development of learning laboratories (gardens and greenhouses) took the classroom outside and reduced the usage of the specimens. Although the complete history of the physical housing of the museum/laboratory cannot be addressed within the constraints of this paper, it is important to reference the space it occupied throughout its existence as a way of measuring its role and value at the institution. For example, Professor Colton notes in a request to President Hewett in December 1888 that the museum "is difficult to keep warm in cold weather," followed by Colton's recommendation that "all the cases containing specimens be kept in the north half of the room, and that end be devoted

\footnotetext{
${ }^{98}$ Keeney, The Botanizers, 137.

${ }^{99}$ Keeney, The Botanizers, 137.

100 "Proceedings of the Board of Education of the State of Illinois, Regular Meeting Held at Normal, December 12, 1888." M.L. Seymour's letter to the Board, 10. Young papers.
} 
chiefly, if not exclusively, to the museum purposes proper, leaving the South end for a class room."

Although the museum has never again seen the prominence it held under Powell, and more significantly, under Forbes, it did remain a fixture on campus. Historical evidence of its existence as a museum is found in ads for specimens in the student newspaper, The Vidette, and it is referenced in recruitment efforts, Board of Education meetings, and in course guides. For example, the Biology courses for the 1909-1910 academic year list the following classes (typographical representation exactly as printed in original text):

Course Two A

Identification of Birds. A half-credit course involving semi-weekly early morning excursions with field glasses, a study of the collections of bird skins in the Museum and assignd readings and reports. Ability to identify redily about one hundred birds is involvd. Spring term. ${ }^{102}$

\section{Course Six}

Entymology. The work is based on the insect life in the vicinity of Normal. Field observations are made with stress laid upon the ecological and economic relations of insects and insect societies. In the laboratory types are studies with special reference to adaptiv structures. Each student is expected to work out in detail the life history of at least one type of insect. The collection, preservation and mounting of specimens with classification is required. Fall term. ${ }^{103}$

\footnotetext{
${ }^{101}$ Proceedings of the Board of Education of the State of Illinois, Regular Meeting Held at Normal, December 12, 1888." B.P Colton's letter to E. C. Hewett, President State Normal University, 15. Young papers.

102 The Illinois State Normal University; Normal School Quarterly, “Annual Catalog Course of Study, 1909-10, Fifty-Second Year," 42. Young papers.

103 The Illinois State Normal University; Normal School Quarterly, “Annual Catalog Course of Study, 1909-10, Fifty-Second Year,” 43. Young papers.
} 
Course catalogs reference the museum and laboratory as part of the curriculum, indicating the continued divergent use of specimens and incorporating the tenets of Nature-Study. This evidence is present through the catalogs dating to 1928-1929.

From 1929 to 2014, there is little accessible evidence of the role or location of the museum and laboratory collections. The museum collections appeared again in 1940 when the library was dedicated in what is now Williams Hall. "The ground floor is devoted principally to the museum - three large exhibit rooms on the west side of the building, and a specially constructed art gallery." ${ }^{\prime 104}$ In the collection of museum-related documents maintained in a private collection by Dr. Marcia Young (former curator of the Museum), there are "Museum Notes" from 1946 and 1953 respectively that recount some of the holdings of the museum and announce what is available to checkout. The 1953 "Museum Notes" is formatted in much the same way that Milner Library's Teaching Materials Center organizes the kits that are loaned out for teacher education students. A partial section of the checklist for the "Realia for Human and Animal Skeletons" is as follows:

Black Bear Skull w/Mandible (cut away \& damaged)

Cow Half-Mandible (left) (loose teeth - Handle With Care)

Cow Vertebra (lumbar)

Coyote Skull w/Mandible

Deer Radii (left) (in bag w/right radii and ulna)

Deer Radii (right) (in bag w/left radii and ulna)

Deer Ulna (right) (in bag w/right and left radii)

\footnotetext{
${ }^{104}$ Illinois State Normal University Bulletin, "Eighty-second Annual Catalog Issue; With Announcements, 1940-41," (May, 1940), 35.
} 
Deer Skull w/Mandible (female) (damaged)

Deer Sternum (in bag w/rib and talus) ${ }^{105}$

The kits include books, activities, games, and other educational aids, as well as recommendations on how to teach the subject. While the human skeleton portions are plastic representations, the animal skeletons are real and may very well date back to an early contribution to the museum by Mr. Ward of Rochester, New York. Forbes noted Mr. Ward's donation in 1873 of "a set of mounted skeletons and detached skulls, so selected as to exhibit the characteristics of the different orders of mammals and of the different classes of other vertebrates."

Establishing the provenance of the scattered museum specimens is one of the challenges facing the institution. Another key question is determining their viability as a resource for researchers. For instance, if the bear skull is determined to be a valuable representation of a regionally extinct population, its lack of care and inadequate storage and handling may have degraded any potential information it could offer.

The 1953 "Museum Notes" also includes a partial list of the objects in the museum's holdings. For example, the Mammals collection includes: "Bat, beaver, duckbilled platypus, hedgehog, mink, muskrat, pine marten, porcupine, prairie dog, rabbit, raccoon, skunk, weasel, wolverine." ${ }^{107}$ The current Milner Library web-site lists the following collection in its Teaching Materials Center Education Kits: "MAMMALS; Beaver, Cottontail, Groundhog, Hedgehog, Mink, Muskrat, Opossum, Porcupine,

\footnotetext{
105 "Teaching Materials Center: Educational Kits," Illinois State University's Milner Library; Teaching Materials Center. http://illinoisstate.libguides.com/c.php?g=30483\&p=191309.

${ }^{106}$ Proceedings of the Board of Education of the State of Illinois, Regular Meeting Held at Normal, June $25 \& 26,1873$, Annexed Report by Prof. S. A. Forbes, Curator of the Museum, 17.

107 "Museum Notes," Illinois State University (October 1953). Young papers.
} 
Raccoon, Skunk." ${ }^{108}$ The mammal collection today has numerous animals that are the same species of specimens that were available in 1953. Additional birds and animals in the Library's teaching center have been established as having been part of Powell's original collection. The provenance of these specimens prompted Milner Library to remove the entire collection from circulation and begin discussions with the Department of Biological Sciences to return them to the laboratory collection currently housed in the Science Laboratory Building in the Powell/Birchenholz Collection.

The previous example demonstrates how far the specimens have come since their inception into the collection at ISNU. It also highlights the challenges that the current curators face in preserving the collection. Tracing the history of the collection is imperative to help locate lost specimens, establish provenance, demonstrate its value, and restore a legacy that has been lost to the campus. The history of the specimens from 1930 to the present day is sporadically accessible, but as demonstrated by the mammals, their use and purpose also continued to be transformed. At some point in their history, some of the animals went to the Milner Library museum and some were retained by Biological Sciences. How and who made the determinations for those moves, as well as why the collection was split apart is information that is lacking. The absence of a distinctive home and purpose for the specimens is a reflection of the conflicted national discourse on education.

\footnotetext{
${ }^{108}$ Illinois State University’s Milner Library, accessed September 9, 2012, http://ilstu.libguides.com/content.php?pid=234250\&sid=1942282.
} 


\section{CHAPTER IV}

\section{RESEARCH AND POLICY USING BIOLOGICAL SPECIMENS}

Collections of biological specimens have been identified as significant historical resources in areas ranging from global warming to epidemiology. A synopsis for a 2004 article on the largely untapped informational capacity of collections provides a summary of current and potential uses:

These biological collections make innumerable contributions to science and society in areas as divergent as homeland security, public health and safety, monitoring of environmental change, and traditional taxonomy and systematics. Moreover, these collections save governments and taxpayers many millions of dollars each year by effectively guiding government spending, preventing catastrophic events in public health and safety, eliminating redundancy, and securing natural and agricultural resources. ${ }^{109}$

This chapter will explore research that has utilized the specimens and how those research findings have been utilized in public policy. Specifically, how scientists use natural history collections to assess the effect of chemicals, climate change, species populations, biodiversity, and evolutionary adaptive strategies in the global environmental systems. The utilization of historic collections for research has grown since the 1980's. A study in 2009 demonstrated the increase of published articles in which biological collections were

\footnotetext{
109 Andrew V. Saurez and Neil D.Tsutsui, "The Value of Collections for Research and Society," BioScience 54, no. 1 (2004): 66.
} 
accessed for research (see table on page 17). ${ }^{110}$ As scholarly centers, universities are where fundamental discourse and research are conducted. The findings of academics inform policy and educate decision makers the knowledge garnered even changes how the past is interpreted. The ability to reconstruct history through the use of collections is not a new precedent however, the ability to reconstruct aspects of the environmental systems has become a matter of global importance, and there is an urgency to the need for this type of knowledge. Global environmental systems are under pressure from humans, and humans are under pressure from the declining health of the very same environmental systems that sustain them.

Perhaps the most high profile event involving science driven policy, historic collections, and actual social/political response, is the global banning of DDT for agricultural use. As one of the most famous and frequently cited examples of use for biological collections, the avian egg specimens used to demonstrate egg thickness prior to, and following, the introduction of DDT as an insecticide in 1945 provide not only an example of use of collections, but how technological advances increased the value of the information they provide. ${ }^{111}$ DDT had been in widespread use for over twenty years when researchers first identified the chemical as a possible cause of "decreases in the thickness of eggshells of certain birds and declines in population sizes for these birds."

The research correlating DDT presence in eggshells was first reported in a study by Dr. Derek Ratcliffe in 1967. A renowned ornithologist and botanist, Ratcliffes' four decades of field observations and research work in Great Britain are considered definitive

\footnotetext{
${ }^{110}$ Pyke, "Biological Collections and Ecological/Environmental Research, 249.

${ }^{111}$ D. B. Peakall, "DDE: It's Presence in Peregrine Eggs in 1948," Science, New Series 183, no 4125 (February 15, 1974): 673.

${ }^{112}$ Pyke, "Biological Collections and Ecological/Environmental Research, 257.
} 
contributions to the field of conservation ecology, land use policy, and invasive species control. In his early years as a field scientist, prior to serving as the Nature Conservancy Council's Chief Scientist, Ratcliffe led a survey researching peregrine falcon populations in Great Britain. His work included observations of smashed eggs in nests and led to the measurement of thickness and density of peregrine falcon eggs from collections. He noted that in egg samples from 1946 and 1947, just one year after introduction of the pesticide DDT, the shells were significantly thinner than the previous forty-six years of egg specimens. ${ }^{113}$ Ratcliffe drew a correlation to the use of organo-chlorine pesticides and published his research in Nature. His theory was initially challenged, particularly by those enterprises with interests in DDT however, it spawned additional research that continued to yield similar findings in collections on multiple continents where DDT had been utilized. ${ }^{114}$ One research study included over 1700 eggs in 39 collections from across the United States and Canada (see Table 2). ${ }^{115}$

\footnotetext{
${ }^{113}$ D. A. Ratcliffe, “Decrease in Eggshell Weight in Certain Birds of Prey,” Nature 215, no. 5097 (1967): 210.

${ }^{114}$ Peakall notes in his publication "DDE in Eggs of the Peregrine Falcon" that in 1972 D.L. Gunn (President of the Association of Applied Biologists in 1972) challenged Ratcliffe's conclusions based on conflicting historical information regarding the timing of the use of DDT in the area of the collection eyries. Gunn stated that "an effect occurring before its cause is utterly unacceptable." Further research validated Ratcliffe's original findings leading to a ban on the use of DDT.

115 Joseph J. Hickey and Daniel W. Anderson, "Chlorinated Hydrocarbons and Eggshell Changes in Raptorial and Fish-Eating Birds," American Association for the Advancement of Science 162, no. 3850 (October 11, 1968): 271.
} 
Table 2: Weights of Raptor Eggshells in Museum and Private Collections

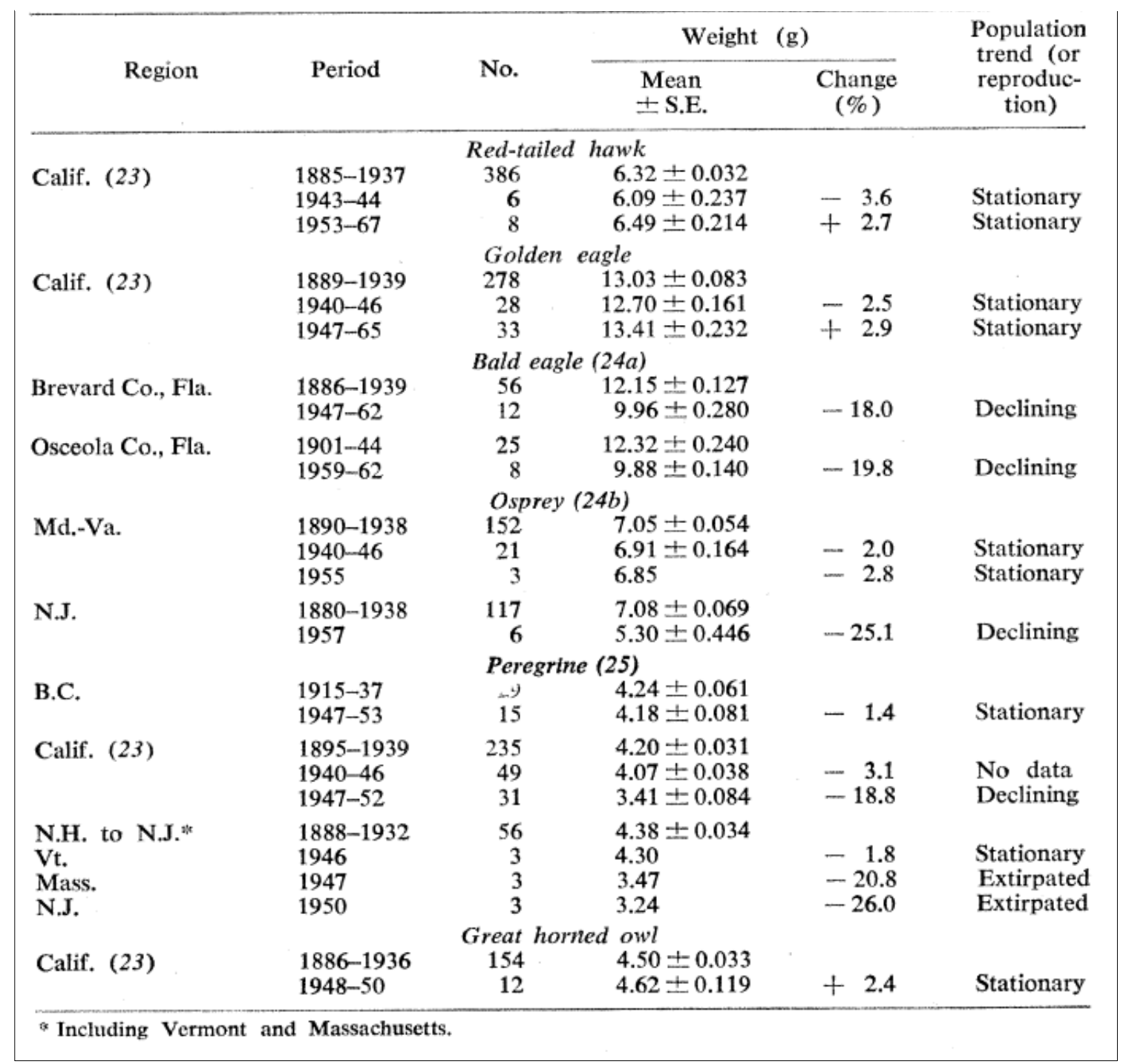

Source: D. A. Ratcliffe, "Decrease in Eggshell Weight in Certain Birds of Prey," Nature 215, no 5097 (1967): 210 .

Note: Thirty-nine collections and over 1700 specimens were utilized to compile a history of eggshell weight and thickness prior to the introduction of the pesticide DDT in 1945, as well as post-application of the chemical.

This North American research study cites the earliest dates of specimens in the collections as 1880 on the east coast and 1885 on the west coast, with a marked drop in specimens collected during and immediately after WWII, a time when the use of DDT escalated. There are specimens available from that era, but the collections are not 
as robust nor are there as many of them. Molecular studies require sampling of the specimens, and while advances in DNA testing now require minimal material, earlier research methods damaged and sometimes destroyed specimens. The political, social and economic implications for DDT usage affected collections around the world. The increased usage of specimens involved potentially damaging research methods which threatened their viability for future research. Becoming evidence in a global power play for indisputable data put them at risk for extinction just at a time when the technology to retrieve those data was becoming more efficient.

Biological collections enabled researchers to identify a probable causal relationship between organic pesticides and their impacts on the reproductive capacity of raptors. Just a few years later in 1973, a similar study also utilizing eggs from collections tested the actual presence of Dichlorodiphenyldichloroethylene (DDE) in eggshells. DDE is a principal metabolite in DDT, and a methodology was developed to test for its presence in the dried membranes of collected egg specimens (see Peakall's table on page 65). ${ }^{116}$ This established a direct causal relationship between the use of DDT and the almost immediate depletion of raptor populations. Further research expanded the scope of the investigation and additional raptor species and specimens were examined to determine the overall impact of the pesticide on organisms and their ecosystems. ${ }^{117}$

\footnotetext{
${ }^{116}$ Peakall, "DDE: Its Presence in Peregrine Eggs in 1948," 674.

${ }^{117}$ Hickey, "Chlorinated Hydrocarbons and Eggshell Changes in Raptorial and Fish-Eating Birds," 271.
} 
Table 3: DDE Residue in Peregrine Falcon Eggs

\begin{tabular}{|c|c|c|c|c|c|c|c|}
\hline \multirow{3}{*}{ Year } & \multirow{3}{*}{ Collection area } & \multirow{3}{*}{$\begin{array}{l}\text { Weight } \\
\text { (g) }\end{array}$} & \multirow{3}{*}{$\begin{array}{c}\text { Thick- } \\
\text { ness } \\
\text { index }\end{array}$} & \multirow{3}{*}{$\begin{array}{c}\text { Fat } \\
(\mathrm{mg})\end{array}$} & \multirow{2}{*}{\multicolumn{2}{|c|}{$\begin{array}{c}\text { Dried } \\
\text { membrane }\end{array}$}} & \\
\hline & & & & & & & \multirow{2}{*}{$\begin{array}{c}\text { Egg } \\
\text { contents } \\
\text { (ppm, } \\
\text { wet } \\
\text { weight) }\end{array}$} \\
\hline & & & & & $\mu \mathrm{g}$ & $\begin{array}{l}\text { ppm } \\
\text { lipid } \\
\text { basis }\end{array}$ & \\
\hline \multicolumn{8}{|c|}{ California eggs } \\
\hline 1894 & San Diego Co. & 4.137 & 1.88 & 0.9 & N.D. & & \\
\hline 1924 & San Luis Obispo Co. & 4.062 & 1.98 & 1.1 & N.D. & & \\
\hline 1935 & San Diego Co. & 5.120 & 2.07 & 1.4 & N.D. & & \\
\hline 1940 & San Luis Obispo Co. & 4.454 & 2.10 & 1.3 & N.D. & & \\
\hline 1948 & San Luis Obispo Co. & 3.726 & 1.66 & 1.0 & 0.050 & 50 & 7 \\
\hline 1948 & San Luis Obispo Co. & 3.964 & 1.87 & 1.8 & 0.040 & 22 & 3 \\
\hline 1949 & San Diego Co. & 3.188 & 1.42 & 0.8 & 0.050 & 62 & 9 \\
\hline 1950 & San Diego Co. & 3.213 & 1.46 & 1.6 & 0.320 & 200 & 30 \\
\hline 1950 & Monterey Co. & 3.854 & 1.64 & 1.8 & 0.045 & 25 & 4 \\
\hline 1968 & Yukon and Colville & $\begin{array}{r}A \\
2.595- \\
3.820 \\
(3.123)\end{array}$ & $\begin{array}{c}\text { kan eggs } \\
1.32- \\
1.64 \\
(1.46)\end{array}$ & $\begin{array}{c}0.9 \sim \\
2.8 \\
(1.7)\end{array}$ & & $\begin{array}{c}41- \\
1005 \\
(225)\end{array}$ & \\
\hline
\end{tabular}

Source: D. B. Peakall, "DDE: It's Presence in Peregrine Eggs in 1948," Science, New Series 183, no 4125 (February 15, 1974): 673

Note: Results of DDE residues in membranes and contents of peregrine falcon eggs. DDE is the principal metabolite in the pesticide DDT.

Even though DDT had been banned for agricultural use in the United States prior to the publication of David Peakall's more definitive research on levels of DDE in Peregrine Falcon eggs, the investigation into its effects continued. ${ }^{118}$ It has a persistent longevity in the environment making it a continuing contaminant and hazard. The Environmental Protection Agency (EPA) notes that it is a cumulative toxin capable of being carried or spread over long distances and because of its environmental endurance there is continued concern of its historic use. ${ }^{119}$ As a result, testing of samples and historic specimens will continue far into the future all across the world, particularly in those areas where DDT and its family of endocrine-disrupting pesticides is still utilized to

\footnotetext{
${ }^{118}$ Peakall, "DDE: Its Presence in Peregrine Eggs in 1948," 674.

${ }^{119}$ Environmental Protection Agency. http://www.epa.gov/pesticides/factsheets/chemicals/ddt-briefhistory-status.htm
} 
control deadly disease vectors such as mosquitos. ${ }^{120}$ The long-term effects of cumulative toxins sometimes take generations to manifest, especially the impacts to reproductive systems, therefore there is additional benefit in studying birds, fish and other animals with shorter generational life spans than humans. By studying the historical impacts on other species, we can better ascertain and mitigate the impacts to humans through policy and public health measures, such as the world-wide agricultural ban of DDT. The study of the impacts of DDT presented the first use of collections in multiple hemispheres of the Earth to track a man-made chemical and cause a world-wide policy to be enacted.

Within the last decade, research on an endangered pod of killer whales included the testing of DDT levels as an investigatory tool to determine what caused the twenty percent decline in a pod of orcas over a period of just five years. A number of research efforts cited persistent organic pollutants (POPs) as a probable causal effect of reproductive decline and the increased jeopardy to the health and survival of calves. It was also discovered that whale pods that fed in the coastal waters of California had higher levels of POPs (and other chemical contaminants) and increased mortality. Informally coined the "California signature," the contamination of prey directly contributes to the contamination of the predator. Fundamentally, the marine ecosystems of California are directly responsible for the decline of population in this particular pod.

A further finding on the reproductive process demonstrated that "maternal transfer of POPs to juveniles has resulted in high levels during a period when their biological systems are undergoing rapid development, so these juveniles may be at greater risk than adults for POP-related health effects (e.g., immune and endocrine

\footnotetext{
120 "The Use of DDT in MalariaVector Control: WHO Position Statement, 2011. World Health Organization. http://whqlibdoc.who.int/hq/2011/WHO_HTM_GMP_2011_eng.pdf?ua=1. 
system dysfunction)." "21 The authors also noted that "reproductive female whales

transfer a substantial portion of their contaminant burden to their calves." ${ }^{122}$ This transfer places the youngest members of the pod in the most jeopardy and ultimately limits the potential recovery of the pod population due to a lack of juveniles maturing to a reproductive age. POP levels in the environment continue to enact substantial impacts to biological systems as evidenced by marine coastal systems and the inland food and water chain that feeds those systems. Although the United States was one of the first to ban its use, DDT continues to have a high rate of residual presence along the northern hemisphere of the Pacific coast. For migratory species, and for the residents of the state of California, these findings have significant implications, yet there are arguments for the use of DDT as well particularly in climates with high mosquito populations. Limited use of DDT has been approved by the World Health Organization (WHO) for areas where the prevalence of malaria and other mosquito borne illnesses are detrimental to the human population. In the 2011 position paper "The Use of DDT in Malaria Vector Control," the World Health Organization states:

The Convention has given an exemption for the production and public health use of DDT for indoor application to vector-borne diseases, mainly because of the absence of equally effective and efficient alternatives. WHO actively supports the promotion of chemical safety and, together with the United Nations Environment Programme, shares a common commitment to the global goal of reducing and eventually eliminating the use of DDT while minimizing the burden of vector-borne diseases.

It is expected that there will be a continued role for DDT in malaria

\footnotetext{
${ }^{121}$ Margaret M. Krahn, M. Bradley Handon, et.al., "Effects of Age, Sex and Reproductive Status on Persistent Organic Pollutant Concentrations in "Southern Resident" Killer Whales," Marine Pollution Bulletin, 58 (2009): 1526.

${ }^{122}$ Krahn, "Effects of Age, Sex and Reproductive Status on Persistent Organic Pollutant Concentrations in "Southern Resident" Killer Whales," 1524.
} 
control until equally cost-effective alternatives are developed. A premature shift to less effective or more costly alternatives to DDT, without a strengthening of the capacity (human, technical, financial) of Member States will not only be unsustainable, but will also have a negative impact on the disease burden in endemic countries. ${ }^{123}$

The WHO's position paper discusses the application protocols, which are strict and limited to indoor applications, and repeatedly emphasizes the need for the development of alternative method of insect control that is effective and affordable. What the WHO does not explicitly state in this nine page doctrine is that the impacts of climate change are forecasted to increase the global area where mosquitos thrive causing an increased need for effective vector-borne disease control methods.

Climate change is a fairly complex process to understand. Climate science assimilates historical data on weather, temperature, solar irradiance, cloud cover, precipitation events, oxygen levels, types of $\mathrm{CO} 2$, and a myriad of other data into forecasting models. ${ }^{124}$ Some of the historical data cover 5 million years and some data sets are only available since humans began measuring and recording atmospheric and weather data. Interpreting climate change to the general public and policy makers is quite challenging. It did not help that the theory was termed "global warming" in the media blitz around the turn of the twenty-first century. The misnomer implied uniform heating of the earth so that when a region experienced record setting cold, the citizens were unable to correlate the theory of climate change to the effects they were experiencing. Global environmental systems are somewhat intangible to the average

\footnotetext{
${ }^{123}$ World Health Organization. "Global Malaria Programme: The Use of DDT in Malaria Vector Control. WHO Position Statement.” 2011, 1.

${ }^{124}$ Intergovernmental Panel on Climate Change, "Climate Change 2013: The Physical Science Basis," Cambridge University Press (2013). http://www.ipcc.ch/report/ar5/wg1/. This report is the fifth iteration.
} 
person, and explaining the complexities in simple and resolute terms is difficult for researchers. The fact that there were 259 authors from 39 countries contributing to the most recent Intergovernmental Panel on Climate Change report demonstrates the complexity of the issue. Translating research findings into personal, regional, or even national impacts is a method that allows the public and policy makers to make informed decisions. This is where leveraging collections from local and regional centers, such as those found in universities, helps people relate to the findings to understand global systems on a more personal level.

Climate change has garnered much attention and much controversy. However, the recent media blitz lags significantly behind science and the observations of the impact of humans on the environment. In the mid-1800's, scientists published the first scholarly works on how humans were impacting the earth. In 1864 George P. Marsh, one of the earliest environmentalists and a peer of John Wesley Powell's, published a book, Man and Nature. In his preface, Marsh notes,

The object of the present volume is: to indicate the character and, approximately, the extent of the changes produced by human action in the physical conditions of the globe we inhabit; to point out the dangers of imprudence and the necessity of caution in all operations which, on a large scale, interfere with the spontaneous arrangements of the organic or the inorganic world; to suggest the possibility and the importance of the restoration of disturbed harmonies and the material improvement of waste and exhausted regions; and, incidentally, to illustrate the doctrine, that man is, in both kind and degree, a power of a higher order than any of the other forms of animated life, which, like him, are nourished at the table of bounteous nature. ${ }^{125}$

${ }^{125}$ George P. Marsh, Man and Nature (Seattle: University of Washington Press, 2003), Preface. 
One of Powell's biographers, Donald Worster, calls Man and Nature "one of the prophetic texts of American conservation," heralding its preliminary call for science to inform human use of the land and the resources derived from it. ${ }^{126}$

In the early 1870 's, different terms were being proposed to describe this change in geological eras as scientists noted that the earth was exiting from the Holocene, a period described as "the post-glacial geological epoch of the past ten to twelve thousand years. ${ }^{2127}$ A trend in the proposed naming of the age has appeared over the last century, and the implications of humans affecting the global systems have dominated the discourse. In 1873 Italian geologist Antonio Stoppani coined the term "Anthropozoic" (of the time of the existence of man). ${ }^{128}$ "Noosphere" (planetary thinking network) was proffered by the French Jesuit paleontologist Pierre Teilhard de Chardin in $1922 .{ }^{129}$ In the last twenty-five years, Eremozoic (era of solitude) and Anthrocene (new human element in geology) were coined respectively by scientists E.O. Wilson and Andrew Revkin. However, it was William J. Stoermer, a professor of biology, studying diatoms at the University of Michigan who coined the term "Anthropocene" (a new geologic epoch marked by human activity) in the 1980's. Renowned atmospheric chemist and Nobel Prize winner Paul Crutzen brought the term to popular culture in an article coauthored by Stoermer in 2000. ${ }^{130}$

${ }^{126}$ Worster, A River Running Through It, 484.

127 Crutzen, "The Anthropocene,"17.

${ }^{128}$ Antonio Stoppani, Corso di Geologia, Excerpts.trans. Valeria Federighi, ed. Valeria Federighi and Etienne Turpin (Miliano: G. Bernardoni, E G. Brigola, Editori, 1873): http://geologicnow.com/2 Turpin+Federighi.php\#sthash.pTojbxgi.dpuf

${ }^{129} \mathrm{http} / / / \mathrm{www}$.gaiamind.com/Teilhard.html as well as noted in "The Anthropocene", 17.

130 Paul J. Crutzen and Eugene F. Stoemer, "The Anthropocene." International Geosphere - Biosphere Programme (IGBP); A Study of Global Change of the International Council for Science (ISCU) Newsletter 41 (May 2000): 17. E.O. Wilson utilized Eremozoic as a representation of homo sapiens dominance of the planet to the exclusion of all else. He stated, "If wild habitat is given over to human cultivation and 
Although widely accepted and utilized by the public and most scientific disciplines, the term "Anthropocene" is not yet a formal designation. ${ }^{131}$ A proposal to formalize the era as the Anthropocene is being developed by a cohort of inter-disciplinary researchers with a target date of $2016 .{ }^{132}$ The group is charged with amassing the data that must be:

(a) scientifically justified (i.e. the 'geological signal' currently being produced in strata now forming must be sufficiently large, clear and distinctive) and (b) useful as a formal term to the scientific community. In terms of (b), the currently informal term 'Anthropocene' has already proven to be very useful to the global change research community and thus will continue to be used, but it remains to be determined whether formalisation within the Geological Time Scale would make it more useful or broaden its usefulness to other scientific communities, such as the geological community. ${ }^{133}$

Data to inform the commission's decision are gathered from many scientific disciplines, and specimen samples are a critical source of that data. Individual samples, and collections as a whole, contain information useful to a wide range of academic practices and purposes. Collectively the information can be utilized to track changes over decades, centuries, and in some cases, millennia.

Three studies in particular demonstrate the diversity of the specimens and methods utilized to recover historical data related to global changes. The first reaches the

habitation, if rainforests can be turned into green deserts, if genetic engineering enables ever-higher yields to be extorted from the thinning soils -- then humans will have created for themselves a new geological era, the Eremozoic, the Era of Solitude, in which little remains on the Earth but themselves and the prosthetic environment that keeps them 'alive'."

${ }^{131}$ Subcommission on Quaternary Stratigraphy, working group. The Subcommission on Quaternary Stratigraphy (SQS) is a constituent body of the International Commission on Stratigraphy (ICS), the largest scientific organization within the International Union of Geological Sciences (IUGS). It is also the only body concerned with stratigraphy on a global scale for the whole geological column. Its most important major objective is the establishment of a standard, globally-applicable stratigraphical scale.

http://quaternary.stratigraphy.org/workinggroups/anthropocene/.

${ }^{133}$ http://quaternary.stratigraphy.org/workinggroups/anthropocene/ 
furthest back in time. Glacial ice cores provide hundreds of thousands of years' worth of atmospheric data compressed into cylinders of frozen history. ${ }^{134}$ The air trapped in ice can provide information that is imperative to understanding atmospheric levels of gases over millions of years. They establish a historic baseline for normal, transitional, and abnormal (or even catastrophic) events. These examples of collection history are referenced here to demonstrate the importance of capturing specimens (biologic or geologic) before they disappear. Ice on a warming planet consequently melts, and valuable historic evidence is disappearing with its demise. Ice is as endangered as the biological life it supports.

In 2008 Eric Rignot, a professor of Earth System Science at UC Irvine and a Senior Research Scientist for NASA, indicated that "Antarctica and Greenland have both lost overall mass at about 120 gigatons of ice per year." ${ }^{135}$ While ice cores are not represented in the collections at Illinois State University, they are similar to soil specimens in that they demonstrate a resource that, if not gathered and preserved, can disappear with the changing climate. Just as glacial ice is disappearing, the soils that have made Illinois one of the most fertile agricultural areas in the world (while holding history in its layers), is getting washed and blown into waterways and eventually dispersing into the Gulf of Mexico. The effects of climate change are destroying the very resources that are needed to study it; hence there is an added urgency in collecting and

\footnotetext{
${ }^{134}$ Michael Bender, Todd Sowers and Edward Brock, "Gases in Ice Cores," Proceedings of the National Academy of Sciences 94, no 16 (1997): 8343-8349.

135 "SOTC: Ice Sheets," State of the Cryosphere; Is the Cryosphere Sending Signals About Climate Change? National Snow \& Ice Data Center, https://nsidc.org/cryosphere/sotc/ice sheets.html. Last updated February 6, 2014. Accessed September 6, 2014.
} 
preserving specimens of all natures, as well as protecting the collections that already exist.

Global changes can be observed on a large scale over millennia as well as on the smallest of scales and in the shortest of life spans. In the second example validating the use of collections for studying climate phenomena, the genetic changes of a tiny fly, with the Latin name of Drosphila subobscura, was tracked on three continents and the adaptations of the insect paralleled climate fluctuations. ${ }^{136}$ The authors stated that "This genetic shift is exceptionally rapid and is detectable in some samples by periods of less than two decades." They went on to cite an increasing number of genetic and phenotypic adaptations that they state are "not surprising from an evolutionary perspective, but nonetheless are disturbing from ecological or economic ones, because such changes signal inevitable disruptions in the distributions, population dynamics, and community interactions of organisms." ${ }^{, 137}$ Simply stated, ecosystems are comprised of millions of symbiotic relationships; a change in one species can be detrimental, and a change in a number of species can be catastrophic.

Insects are generally highly adaptive and quick to respond to environmental changes therefore, they are a preliminary indicator of a disruption in an ecosystem. Some of the other indicator species are the flora, also highly susceptible to subtle changes. Any gardener will delight in discussing which soil nutrients, water, and light are most amenable to their prized vegetables or flowers, as well as how to spot when the health of the plant is diminished. The herbaria around the world contain specimens that can

\footnotetext{
${ }^{136}$ Joan Balanya, Josep M. Oller, Raymond B. Huey, George /w. Gilchrist, and Luis Serra, "Global Genetic Change Tracks Global Climate Warming in Drosophila Subobscura," Science 313 (September 2006): 1773-1775.

${ }^{137}$ Balanya, “Global Genetic Change Tracks Global Climate Warming in Drosphila Subobsura,” 1775.
} 
provide researchers with that very same information. This is the case with the third example, the use of orchids to collect data for climate change studies. Using herbarium specimens requires that the specimen have a location, date, and time of collection the life stage of the specimen is evident if well preserved. This particular study utilized over a century of spider orchids (1848 to 1958) from the herbaria of the Natural History Museum in London. Of the specimens that were relevant to the research, fifty-three percent were rejected for use based on the inadequacy of the records or poor quality of the specimen.

As discussed earlier, the competency of the collector plays a major role in the validity of the research. The phenological events of the accepted specimens were then compared to relevant weather and atmospheric data to draw timelines for data such as budding time, flowering, seeding, and dormancy. Sustained variations in the timing of events, such as flowering and lengths of dormancy, are indicative climate fluctuations. The purpose of this particular orchid study was to demonstrate the viability of natural history collections in climate change research, and the researchers note that "For most species of plants and animals, biological collections are the only source of long-term phenological data." ${ }^{\prime 138}$ It has been estimated that there are 2.5 billion biological and herbarium specimens in collections throughout the world. ${ }^{139}$ Even if only half are viable, there is an astounding abundance of untapped resources available for research.

\footnotetext{
${ }^{138}$ Karen M. Robbirt, Anthony J. Davy, Michael J. Hutchings, and David L. Roberts, "Validation of Biological Collections as a Source of Phenological Data for Use in Climate Change Studies: A Case Study With the Orchid Ophrys Sphegodes," Journal of Ecology 99 (2011): 240.

${ }^{139}$ Catherine H. Graham, Simon Ferrier, Falk Huettman, Craig Mortiz, and A. Townsend Peterson, "New Developments in Museum-Based Informatics and Applications in Biodiversity Analysis," TRENDS in Ecology and Evolution 19, no. 9 (September 2004): 497.
} 
As climate change studies have demonstrated, contemporary researchers utilize historic specimens to generate baseline information, as environmental indicators, and as genetic markers on an evolutionary time continuum. Although the collections and specimens were not gathered and prepared to serve these purposes, their continued relevance helps to preserve them and the historical information they contain. The types of research they can be used for varies, as do the methods of research. Some research, such as the orchid sampling is non-invasive, while other research requires more probative sampling, such as that needed for DNA and diatom research. Preservation and mounting methods did not account for the needs of molecular sampling, but technology has enabled the gathering of that type of information with minute quantities of raw material. That has not always been the case, as in the example of testing for the presence of the pesticide DDT, but advanced sampling methods have broadened the type of research that can be performed on specimens. This has enabled targeted research which has been especially useful in the areas of conservation biology and species diversity.

Reproductive capacity is not only affected by chemicals and maternal transference, but it can also be affected through availability of mating partners. Habitat loss has had a significant global impact on species populations and genetic diversity. From issues such as urban sprawl to mass transportation infrastructure, human systems greatly impede natural migrations, territories, sex, and reproduction. While there are many research efforts ongoing in institutions worldwide, two research efforts in particular, one in the United States and one in Europe, prominently demonstrate the use of collected historic specimens in evaluating genetic diversity in conservation biology. 
In 2003, Craig Miller and Lisette Waits published a study examining whether the Yellowstone Grizzly Bear was experiencing a loss of genetic diversity due to human factors such as isolation (loss of wildlife corridors between the park and other bear populations), closing of dumps, and destruction of nuisance bears. They examined 110 museum grizzly bear specimens that had been collected between 1912 and 1981. Their findings were presented in the "The History of Effective Population Size and Genetic Diversity in the Yellowstone Grizzly: Implications for Conservation." The research in this case was to test the hypothesis that "during a century of anthropogenic isolation and population size reduction," significant inbreeding had occurred causing diminished genetic variability in the Yellowstone population compared to other grizzly bear populations in North America. Political and legal implications of the research findings were important, as shown by a ruling against the U.S. Fish and Wildlife Service for its failure to meet the recovery planning obligation of the Endangered Species Act which specified it had to ensure there was enough space to support a viable population. The federal department was cited for "paying insufficient attention to the risk of genetic isolation" in the Yellowstone grizzly population. ${ }^{140}$

The historic specimens sampled were from four institutions: the Smithsonian Institution, National Museum of Natural History (Washington, DC); the California Academy of Sciences (San Francisco); the University of Montana Zoological Museum (Missoula, MT); and the Montana Department of Fish, Wildlife and Parks (Bozeman, MT). The DNA analyses of these specimens were obtained by gathering approximately

\footnotetext{
${ }^{140}$ Craig R. Miller, Waits, Lisette P., "The History of Effective Population Size and Genetic Diversity in the Yellowstone Grizzly (Ursus arctos): Implications for Conservation," Proceedings of the National Academy of Sciences of the United States of America 100, no. 7 (April 1, 2003): 4334.
} 
$0.4 \mathrm{~g}$ of bone from the cranial cavity of skulls. DNA comparators from contemporary specimens were obtained from hair samples and other research on the genetics of this bear population in North America. The history of bear activity in the park, specifically as it related to the closure of the dumps in the park, was a key time stamp marker for the researchers. The garbage dumps attracted bears into the proximity of humans, increasing the need to relocate or cull nuisance animals. The garbage dumps were gradually eliminated between 1968 and 1971, and during a slightly expanded time frame (1967 to 1972) 220 known mortalities occurred. These deaths decreased the available genetic pool within this isolated population, allowing researchers to analyze two delineated eras in the park history of the bears. The first set of sampled bears was from 1912 to 1920 . The second set of historic DNA was gathered from 1959 to 1981 . Both sets of samples were from bears in the collections of the aforementioned institutions. The results of the study demonstrated that although genetic diversity had declined slightly since the early $20^{\text {th }}$ century, the Yellowstone Grizzly Bear population is "unlikely to be compromised by genetic factors in the near future."141

The study provided several scenarios for maintaining the genetic diversity of the species, most notably habitat management and the expansion of ranges through maintenance of wildlife corridors that would provide access to neighboring populations of grizzlies. The study also notes that,

The use of historical specimens for genetic study also demonstrates how museums and museum collections continue to play an important role in

\footnotetext{
${ }^{141}$ Miller, "The History of Effective Population Size and Genetic Diversity in the Yellowstone Grizzly (Ursus arctos)": 4338.
} 
conservation and management, despite an atmosphere of budget cuts and a misconceived reputation for being obsolete. ${ }^{142}$

The provenance and availability of specimens is as important to research as the protocols for authenticating historic genetic samples. Even as advancements in molecular testing have created a new era of relevancy for collected specimens, the evolving technology comes with restraints, questions of veracity, and new methodologies that challenge current preservation methods. A European study, similar to the research on genetic variance of the Yellowstone Grizzly, surveyed historic specimens to aid in the conservation of the critically endangered Iberian Lynx. Data were gathered to ascertain the relevancy and value that private and other small collections could provide beyond professional and museum collections. ${ }^{143}$

This particular European study, published in December 2012, cited survey efforts dating back several decades, to catalogue existing specimens and extant populations. ${ }^{144}$ The authors noted that in large museums, there was a general lack of electronic databases and that there is a preponderance of specimens from limited geographic areas and time frames. The study found that specimens from private collections and small museums helped to fill geographic and time gaps. ${ }^{145}$ It is also noted by the authors that sampling solely from large museum collections may bias data procurement because there is a “tendency of some large museums' collections to be concentrated in certain time periods

\footnotetext{
${ }^{142}$ Miller, "The History of Effective Population Size and Genetic Diversity in the Yellowstone Grizzly (Ursus arctos)": 4338.

${ }^{143}$ Mirea Casas-Marce, Eloy Revilla, et. al., "The Value of Hidden Scientific Resources: Preserved Animal Specimens from Private Collections and Small Museums," BioScience 62, no 12 (December 2012): 1077-1082.

${ }^{144}$ Authors of the article utilized research from a 1992 survey by Rodrigues and Delibes in which they had determined the range and status of the Iberian Lynx in 1824 Spain.

${ }^{145}$ Casas-Marce, "The Value of Hidden Scientific Resources, " Figure 1 notes the spatial distribution of specimens and their decade of capture.
} 
and areas." ${ }^{146}$ In this study Illinois State University's collections would fall into the large museum category. Similarly to the Yellowstone Grizzly study, habitat loss was a major contributing factor to the decimation of the Iberian Lynx population. Unlike the grizzly study, the majority of the data samples were from specimens in private collections.

Sampling of the diversity of collections has demonstrated that there are "geographic, temporal and taxonomic" biases; hence the need to expand the scope of what is readily available to researchers by leveraging global networks and databases. ${ }^{147}$ The limitations of each collection to provide a robust representation of a species, time period, or geographic region are prevalent in many collections, so there is a need to access private and small collections that can fill in the gaps. Additionally, collection bias has played a role in the diversity of available specimens. Early collection efforts were not governed or guided by standards that produced robust and representative samples.

Elizabeth Keeney notes in "The Botanizers" that "While particularly enthusiastic botanizers sometimes took long collecting trips, most stayed fairly close to home." 148 As human habitations spread west and the opportunities for alternative forms of transportation expanded, so did the opportunities for collection. However, even these forays into the wild were proximate to anthropogenic influence. Excerpts from early botanical collectors describe following narrow lanes, woodland paths, bogs, potato patches, and railroad lines. These areas were interspersed among and along people's homes, thoroughfares, and agricultural endeavors, far from the wilderness that Powell

\footnotetext{
${ }^{146}$ Casas-Marce, “The Value of Hidden Scientific Resources, ” 1078.

${ }^{147}$ Garcia-Milagros, Eduardo and Funk, Vicki A., "Improving the use of information from museum specimens: Using Google Earth to georeference Guiana Shield specimens in the US National Herbarium." Frontiers of BioGeography 2.3 (2010): 71.

${ }^{148}$ Keeney, The Botanizers, 14-15.
} 
and Vasey had surveyed. Several studies that have examined the location of collections through a georeferencing process have resulted in a map that "generally resembles a map of human habitation and connecting roads." ${ }^{149}$ Georeferencing is the process of applying present day coordinates to a location.

Regardless of who did the collecting and where specimens were gathered, it is the curator of the collection that ultimately has responsibility for what is contained in a collection. Curators are also subject to bias, and their proclivities and preferences for what should or should not be part of a collection effects what stays and what goes. In a 2003 paper on systematics, Stanford Biology Professor Paul R. Ehrlich noted such an instance:

The sampling of nature represented by traditional collections is still usually the exact opposite of "systematic" - emphasizing "good specimens" and adults. In the past it has sometimes been openly biased. I well remember N.D. Riley, keeper of the Lepidoptera collections at the British Museum (Natural History) (now the Natural History Museum, London), bragging to me in the 1960s that for a century the Museum had been buying collections, saving the "aberrations," and discarding the 'junk. ${ }^{150}$

It was often the unique or unusual specimens that were selected precisely because they did not conform to the defining characteristics of a species. While such samples are still useful, it is the collections that represent a species population in its entirety including the common as well as the uncommon anomalies - that provide the most information from an eco-historical context. Collections that broadly represent specimens including various sex, age and seasonal attributes provide researchers with a picture of

\footnotetext{
${ }^{149}$ Pyke, "Biological Collections and Ecological/Environmental Research," 253.

${ }^{150}$ P. R. Ehrlich, "Twenty-first Century Systematics and the Human Predicament," Biodiversity: Past, Present and Future, Proceedings of the California Academy of Sciences 56, supplement 1, no.4 (2005): 131-132.
} 
what the ecological system looked like as a whole. Distinctive qualities that are deviant from normative species characteristics can be indicative of an adaptation signaling a change in the ecosystem. As has been demonstrated, these ecological indicators can highlight the presence of chemicals, climate shifts, and population fluctuations. Such disruptions can initiate public response to potentially catastrophic and harmful environmental conditions.

The restriction of a globally utilized family of chemicals is just one example of how collections have come to serve public policy. As the world and the sciences have evolved, so have the potential uses for the millions of specimens stuffed in drawers and closets in collections around the world. Ironically in the middle of the twentieth century, even as Illinois State University's collections were decaying and in a state of neglect, one of the earliest discoveries that would transform the relevance of the collections was being developed, that of DNA in 1953. Although DNA typing would not be leveraged on historic specimens for another thirty years, it provided a portal into the systematics of classification that had never before been possible. Prior to the coding of life that DNA allows, there were more primitive studies of genetics based on physiological characteristics, geography, and behaviors. Visually distinctive markings, mating rituals, and parenting strategies have historically been utilized to group animals, plants, and humans into categories and lineages.

DNA research continues to present new opportunities for everything from criminal justice to manipulating inherited genetics. Technological advances in the field during the first decade of the twenty-first century have enabled research opportunities that were unimaginable in 1857. In regard to the biological and plant specimen 
collections around the world, it has created a windfall of data sources for researchers.

The American Museum of Natural History in New York, as well as the Natural History Museum of London, have dedicated DNA programs and projects to gather the genetic code of their holdings. As recently as twenty years ago, the technology for DNA sampling was not precise enough to leverage the full potential of the collections however, "given the small amount of tissue now needed for extracting sufficient amounts of DNA... few specimens should be out of bounds for molecular studies."151 The value of the genetic information that can be derived from the collections has implications for public health and safety, agriculture, habitat loss, biological invasions, and global climate change. ${ }^{152}$

Collecting and sampling of specimens are no longer limited in purpose to simple observation of external characteristics or dissection to study physiology. Each specimen, past and future, holds valuable information, and maintaining the integrity of historical specimens is critical to those possibilities. Preservation methods of specimens now consider not only current techniques and research capacity, but also take into consideration what the future may enable. Sampling of the diversity of collections has demonstrated that there are biases in collections, either through the collection process or through the collection's curators therefore, there is a need to fill in the gaps and expand the scope of what is readily available to researchers by leveraging global networks and databases. ${ }^{153}$ The limitations of each collection to provide a robust representation of a species, time period, or geographic region is being overcome with the availability of

\footnotetext{
${ }^{151}$ Peter Wandeler, Paquita E.A. Hoeck and Lukas F. Kellar, "Back to the Future: Museum Specimens in Population Genetics," TRENDS in Ecology and Evolution 22, no. 12 (2007): 637.

${ }^{152}$ Suarez, "The Value of Museum Collections for Research and Society," 66-73.

${ }^{153}$ Garcia-Milagros, "Improving the Use of Information From Museum Specimens, 71.
} 
technology and the willingness to share the vast resources in holdings throughout the world. 


\section{CHAPTER V}

\section{CHANGING HISTORY: THE SECRETS IN DRAWERS AND CLOSETS}

Collections in school systems and institutions continue to provide valuable insight into history. Just three years ago a passenger pigeon specimen was discovered in a collection at Millikin University that post-dates the accepted extinction date of the species in the wild. This year marks the centenary of the disappearance of the bird from the planet, the last captive bird died at the Cincinnati Zoo in 1914, and will be commemorated with a series of events and publications. ${ }^{154}$ The passenger pigeons' demise was a call to arms for wildlife conservation and a historical example that demonstrates the fragility of a species. Numbered at a population of 3 billion in the early 1860 's, just over forty years later, they were extinct. The Peggy Notebaert Nature Museum in Chicago, Illinois has unveiled an exhibit ("Nature's Struggle: Survival \& Extinction") that uses the "passenger pigeon story to show how biodiversity and the environment have changed over time." ${ }^{\prime 55}$ The labeling and established provenance of that one specimen changed accepted history.

Labeling of specimens does not always include the notes and field records of the collector. This disassociation creates a problem for the curators of historical collections

\footnotetext{
${ }^{154}$ The discovery of the last known wild passenger pigeon is discussed in Joel Greenberg's book $A$ Feathered River Across the Sky: The Passenger Pigeon's Flight to Extinction (New York: Bloomsbury Publishing, 2014). The specimen itself is a showcase piece for the event, and for Millikin University.

155 “Nature's Struggle: Survival \& Extinction," Event Web-site accessed October 5, 2014, http://www.dnainfo.com/chicago/20140122/lincoln-park/from-5-billion-nature-museum-marks-100th-yearof-birds-extinction.
} 
in their ability to establish provenance, and to make the specimens available for global research through electronic databases. There is a global effort underway to create databases of specimen information so that researchers can be provided "tools for visualizing and analyzing specimen records from multiple collections."156 A new field, combining biological research, computer technology, geography, and many other sciences, is called "Biodiversity Informatics." The vision for this extensive global program is to allow researchers from anywhere on the planet to utilize specimens, housed anywhere on the planet, to "investigate complex evolutionary and ecological phenomena" in an effort to "meet the challenge of the biodiversity crisis by providing scientific basis for the decisions facing society regarding the stewardship of life on earth."157 In a study on the potential uses for this type of informatics, the authors speak eloquently about the benefit for dispersed collections. The authors state that this level of information "allows us to show the power of examining georeferenced data from the standpoint of 'all collections from an expedition' rather than 'all collections from a single area'."158 In the case of the John Wesley Powell Surveys, it would be possible to gather specimen information from the dispersed collections to provide an ecosystem level understanding of the Colorado River system and Plateaus of 1868 and 1873, respectively.

The potentiality of uses is not limited to spatial data. It can, and has been, expanded to involve taxonomy, species adaptations, evolutionary population distribution,

\footnotetext{
${ }^{156}$ Paul C. Murphey, Robert P. Guralnick, et.al., "Georeferencng of Museum Collections: A Review of Problems and Automated Tools, and the Methodology Developed by the Mountain and Plains SpatioTemporal Database-Informatics Initiative (Mapstedi)," PhyloInformatics; Journal for Taxonomists 3 (2004): 2.

${ }^{157}$ Murphey, Georeferencng of Museum Collections, 2.

${ }^{158}$ Murphey, Georeferencng of Museum Collections, 71.
} 
epidemiology, conservation genetics, invasive species management, and more. ${ }^{159}$ Illinois State University participates in both the Mammal Networked Information System (MANis initiative) operated by the National Science Foundation, as well as the Global Biodiversity information Facility (GBIF) database, operated and funded by an international collaboration of governments and agencies. ${ }^{160}$ These resources maintain information on millions of specimens, species, collections, and published works on biodiversity which is available for free to everyone. They also provide resources to enable the addition of data from collections such as those housed at Illinois State University. The collections at ISU were obtained from areas across the nation, so an important piece of each specimen's dataset is the location where it was gathered.

Georeferencing is the process of assigning geographical coordinates to a specimen. Today's collectors can carry a GPS (geographical positioning system) unit with them to identify the precise location, date and time of day. Most historical specimens do not come with that level of detail, and a universal process by which museum specimens are assigned a coordinate is still in development. There are several protocols and systems that work very well in this venture, but the global scientific community has yet to agree upon a single standard and method.

\footnotetext{
${ }^{159}$ Murphey, Georeferencng of Museum Collections, 71.

${ }^{160}$ Global Biodiversity Information Facility database, accessed February 21, 2015, http://www.gbif.org/dataset/search?q=Illinois+State+University
} 
Table 4: Examples of Databases of Bio-Informatics

\begin{tabular}{|c|c|c|c|c|}
\hline Full name & Key information ${ }^{a}$ & $\begin{array}{l}\text { Taxonomic } \\
\text { coverage }\end{array}$ & $\begin{array}{l}\text { Geographical } \\
\text { coverage }\end{array}$ & Web address \\
\hline $\begin{array}{l}\text { Global Biodiversity } \\
\text { Information Facility } \\
\text { (GBIF) }\end{array}$ & $\begin{array}{l}64 \text { organizations } \\
\text { and/or collections } \\
\text { from various } \\
\text { countries }\end{array}$ & Broad & Global & http://www.gbif.org/ \\
\hline $\begin{array}{l}\text { The World Information } \\
\text { Network on Biodiversity } \\
\text { (REMIB) }\end{array}$ & $\begin{array}{l}25 \text { collections from } \\
\text { various countries }\end{array}$ & Broad & 146 Countries & $\begin{array}{l}\text { http://www.conabio.gob.mx/remib_ingles/doctos/remib_ing. } \\
\text { html }\end{array}$ \\
\hline $\begin{array}{l}\text { European Natural } \\
\text { History Specimen } \\
\text { Information Network }\end{array}$ & $\begin{array}{l}\text { Seven partners from } \\
\text { Europe }\end{array}$ & Broad & Europe & http://www.nhm.ac.uk/science/rco/enhsin/ \\
\hline $\begin{array}{l}\text { Australian Biodiversity } \\
\text { Information Facility } \\
\text { (ABIF) }\end{array}$ & $\begin{array}{l}\text { Three data } \\
\text { providers } \\
\text { representing } \\
\text { various NHCs }\end{array}$ & Broad & Australia & http://www.deh.gov.au/biodiversity/digir/index.html \\
\hline $\begin{array}{l}\text { The Biota of Canada } \\
\text { Information Network } \\
\text { (BC|F) }\end{array}$ & $\begin{array}{l}40 \text { Canadian NHC } \\
\text { collections }\end{array}$ & Broad & Canada & http://www.durable.gc.ca/group/biota/index_e.phtml \\
\hline $\begin{array}{l}\text { Distributed Information } \\
\text { Network for Biological } \\
\text { Collections (SpeciesLink) }\end{array}$ & $\begin{array}{l}12 \mathrm{NHC} \text { in São Paulo } \\
\text { state, Brazil }\end{array}$ & Broad & Brazil & $\begin{array}{l}\text { http://splink,cria.org.br/ } \\
\text { index?\&setlang }=\text { en }\end{array}$ \\
\hline $\begin{array}{l}\text { Instituto Nacional de } \\
\text { Biodiversidad (INBio/Atta) }\end{array}$ & One institute & Broad & Costa Rica & http://atta.inbio,ac.cr/attaing/atta03.html \\
\hline $\begin{array}{l}\text { Mammal Networked } \\
\text { Information System } \\
\text { (MANIS) }\end{array}$ & $\begin{array}{l}17 \mathrm{NHC} \text { from North } \\
\text { America }\end{array}$ & Mammals & World & http://dlp.cs,berkeley.edu/manis/ \\
\hline Fishnet & $\begin{array}{l}24 \text { North American } \\
\text { NHC of fish }\end{array}$ & Fish & North America & http://habanero.nhm.ku.edu/fishnet/ \\
\hline HerpNET (HerpNet) & $37 \mathrm{NHC}$ collections & Broad & Global & http://herpnet.org/ \\
\hline $\begin{array}{l}\text { Missouri Botanical } \\
\text { Garden (Tropicos) }\end{array}$ & One institute & Plants & Global & http://mobot.mobot.org/W3T/Search/vast.htmI \\
\hline
\end{tabular}

abbreviation: NHC, natural history collections.

Source: Catherine H. Graham, et al., "New Developments in Museum-Based Informatics and Applications in Biodiversity Analysis." Trends in Ecology and Evolution 19, no. 9 (2004): 498.

Beyond the computational science, there is the challenge of what data exist with older collections and how translatable it is to electronic language parameters. This is an example of why the photographs and paintings that were part of the Powell survey are so important to the value of the specimens. Vasey had been a part of the first survey in 1868, and his collections on that expedition would benefit equally from the information available on the photo plates. The ability to pull reference data from an entire survey would greatly expand research capacity. Georeferencing is applicable to artifacts as well as specimens, opening a host of additional opportunities for archaeology, history, sociology and other areas of study.

Powell, in particular collected significant amounts of artifacts in his surveys. Although it was not his priority, it was fundamentally a condition of his funding. 
Powell's role at the Smithsonian was as its first head of the Department of Ethnology, established in 1879. The study of people was a passion of his, and his experience with indigenous populations during his surveys gave him a profound understanding of how the land and people interacted. His passions were subverted by the Secretary of the Smithsonian, Spencer Fullerton Baird, who had a penchant for artifacts, little use for the study of languages, and a bad habit of diverting congressionally appropriated funds from Powell's expeditions. Although Powell did receive criticism for taking portions of his collections with him to the Smithsonian when he left Illinois State Normal University, he did in fact replace the artifact collection. Forbes noted that, The specimens of Indian arts received from Maj. J. W. Powell replace those sent by him from our Museum to the Smithsonian Institution at Washington. Although the collection is not the same as the one removed, it appears to be of equal value. ${ }^{161}$

While the artifacts hold value and information, the biological collections contain a prominent piece of information that has only recently been tapped.

The status of the collections in 2014 is far different from the one that Powell is credited with amassing. During the last century and a half, the original inventory of the Illinois Natural History Society has been widely dispersed as its value to education has fluctuated. The original collections have been broken apart and dispersed, they have also been added to, and in some cases, repurposed. While some individual specimens and artifacts have been separated from the collections, three principal repositories remain: the Vasey Herbarium, the John Wesley Powell \& Dale Birkenholz Natural History

\footnotetext{
${ }^{161}$ Proceedings of the Board of Education of the State of Illinois, Regular Meeting Held at Normal, June $25^{\text {th }}$ and $26^{\text {th }}, 1873$. Report by S. A. Forbes: $17-18$.
} 
Collections (NHC), and the Learning Resource Center in the Department of GeographyGeology.

There are limited resources available to maintain these collections. They are currently curated by faculty who are only able to devote limited time to the collections, but they are utilized for student research. What is lacking in the current situation is concerted and coordinated effort to leverage the collections to obtain the resources needed to properly catalogue specimens, maintain them, and make them available to a wider audience for consolidation into the global species information database.

Professor Forbes perhaps summarized the efforts of the early collectors best when he discussed how the sciences would endure for many decades forthcoming "by which time we shall all have been long relieved from our responsibilities, and the labors and honors of scientific enterprise will have been handed on to our remote successors." ${ }^{162}$ His foresight was correct, and while the scientists and citizens that benefit from those early collectors and curators may not necessarily know their names, the evidence of their efforts abounds in drawers and specimen cases in every country around the world.

\footnotetext{
${ }^{162}$ Stephen A Forbes, "History of the Former State Natural History Societies of Illinois," Science, New Series, XXVI, (July-December 1907), New York, The MacMillan Company: 678.
} 


\section{BIBLIOGRAPHY}

\section{PRIMARY SOURCES}

Board of Education of the State of Illinois. Minutes and Letters of the Board of Education for Illinois. Proceedings of June 24, 1885. Printed by H.W. Rokker, State Printer and Binder, Springfield, Illinois.

Forbes, Stephen A. "History of the Former State Natural Historical Societies of Illinois." Transactions of the Illinois State Academy of Science 1-3 (1908-1910): 18-30. Accessed March 26, 2012. www.biodiversitylibrary.org/item/52426.

Illinois State Board of Education, "Proceedings of the Board of Education, State of Illinois, 1866" (1866), Regular Meeting Held at Normal December 19, 1866 (University Publications, Paper 58). Available through the Dr. Jo Ann Rayfield Archives at Illinois State University, http://ir.library.illinoisstate.edu/univpubs/58.

Illinois State Board of Education, "Proceedings of the Board of Education, State of Illinois, 1873" (1873), Regular Meeting Held at Normal June 25 \& 26, 1873 (University Publications, Paper 17). Available through the Dr. Jo Ann Rayfield Archives at Illinois State University, http://ir.library.illinoisstate.edu/univpubs/17.

Illinois State Board of Education, "Proceedings of the Board of Education of the State of Illinois, 1878; Stephen A Forbes Annual Report of The Illinois State Laboratory of Natural History" (1878). Proceedings of the Board of Education of the State of Illinois. Paper 22: 13-24. http://ir.library.illinoisstate.edu/univpubs/2.

Illinois State Board of Education, "Proceedings of the Board of Education of the State of Illinois: Regular Meeting Held at Normal, June 24, 1885." Private Collection of Dr. Marcia Young.

Illinois State Board of Education, "Proceedings of the Board of Education of the State of Illinois: Regular Meeting Held at Normal, Dec. 9, 1885." Private Collection of Dr. Marcia Young.

Illinois State Board of Education, "Proceedings of the Board of Education of the State of Illinois: Regular Meeting Held at Normal, Dec. 12, 1888." Private Collection of Dr. Marcia Young. 
Illinois State Normal University, Normal School Quarterly, "Annual Catalog Course of Studey, 1909-10, Fifty-Second Year.” Private Collection of Dr. Marcia Young.

Illinois State University, "Museum Notes" (1946). Private Collection of Dr. Marcia Young.

Illinois State University, "Museum Notes" (October 1953). Private Collection of Dr. Marcia Young.

Illinois State University, “A Brief History of Biological Sciences at I.S.U.” Received by the Office of the President of I.S.U., August 11, 1964. ). Private Collection of Dr. Marcia Young.

Powell, J. W. "Report on the Lands of the Arid Region of the United States, With a More Detailed Account of the Lands of Utah; With Maps." U.S. Geographical and Geological Survey of the Rocky Mountain Region: U.S. Printing Office, 1879. http://pubs.er.usgs.gov/publication/70039240

Vasey, George W. "Report of an Investigation of the Grasses of the Arid Districts of Kansas, Nebraska, and Colorado." Department of Agriculture Botanical Division Bulletin No. 1. Washington: Government Printing Office, 1886.

Vasey, George W. and George Engelmann, Correspondence from 1849-1883. Biodiversity Heritage Library. Accessed April 30, 2014. http://www.biodiversitylibrary.org/item/152430\#page/11/mode/1up.

\section{SECONDARY SOURCES}

Attebury, Ramirose and Michael Kroth. "From Pedagogical Museum to Instructional Material Center: Education Libraries at Teacher Training Institutions, 1890s to 1970s." Education Libraries 35, no. 1-2 (2012): 48-58.

Balanyá, Joan, et al. "Global Genetic Change Tracks Global Climate Warming in Drosophila Subobscura.” Science 313, no. 5794 (2006): 1773-1775.

Bates, Ralph S. Scientific Societies in the United States. New York: Columbia University Press, 1958.

Bell, Christopher J. and Jim I. Mead. "Not Enough Skeletons in the Closet: CollectionsBased Anatomical Research in an Age of Conservation Conscience." Anatomical Record-Advances in Integrative Anatomy and Evolutionary Biology 297, no. 3 (2014): 344-348. 
Bender, Michael, Todd Sowers, and Edward Brook."Gases in Ice Cores."Proceedings of the National Academy of Sciences 94, no. 16 (1997):8343-8349.

Berg, W., et al., "Mercury Content in Feathers of Swedish Birds from the Past 100 Years," Oikos 17 (1966): 71-83.

Brooke, M. de L. "Why Museums Matter."Trends in Ecology and Evolution 15, no.4 (2000): 136-137.

Burger, Joanna, et al., "Heavy Metal Concentrations in Feathers of Common Loons (Gavia immer) in the Northeastern United States and Age Differences in Mercury Levels," Environmental Monitoring and Assessment 30 (1994): 1-7.

Canby, Wm. M. and J. N. Rose. "Vasey: A Biographical Sketch." Botanical Gazette 18, no.5 (1893): 170-183.

Casas-Marce, Mireia, et al. "The Value of Hidden Scientific Resources: Preserved Animal Specimens from Private Collections and Small Museums." BioScience 62, no. 12 (2012):1077-1082.

Collins, Ed, "Searching for Doctor Vasey,"Chicago Wilderness Newsletter, 2001. http://www.chicagowilderness.org/CW_Archives/issues/winter2001/vasey.html

Conn, Stephen. Museums and American Intellectual Life, 1876-1926. Chicago: The University of Chicago Press, 1998.

Conniff, Richard. "Meet the Species.” Smithsonian 41, no. 4 (2010): 50 http://www.smithsonianmag.com/40th-anniversary/meet-the-new-species$748819 /$.

Cox, Peter M. "Acceleration of Global Warming Due to Carbon-Cycle Feedbacks in a Coupled Climate Model." Nature 408 (2000): 184-187.

Crutzen, Paul J. and Eugene F.Stoemer, "The Anthropocene." International Geosphere Biosphere Programme (IGBP); A Study of Global Change of the International Council for Science (ISCU)Newsletter 41 (2000):17-18.

Daniels, George H. Science in American Society: A Social History. New York: Alfred A. Knopf, 1971.

“DDT,” U.S. Environmental Protection Agency, accessed August 16, 2014. http://www.epa.gov/pbt/pubs/ddt.htm.

Dosch, Jerald J. "On Dead Birds' Tales: Museum Specimen Feathers as Historical Archives of Environmental Pollutants." Environmental History 12 (2007): 661665 . 
Drew, Joshua. "The Role of Natural History Institutions and Bioinformatics in Conservation Biology" Conservation Biology 25, no. 6 (2011): 1250-1252.

Ehrlich, P.R. "Twenty-first Century Systematics and the Human Predicament." Biodiversity: Past, Present and Future, Proceedings of the California Academy of Sciences 56, supplement 1, no. 4 (2005): 130-148.

Ellis, Rebecca. "Rethinking the Value of Biological Specimens: Laboratories, Museums and the Barcoding of Life Initiative." Museum and Society 6, no.2 (2008): 172191.

Garcia-Milagros, Eduardo and Vicki A.Funk. "Improving the Use of Information From Museum Specimens: Using Google Earth to Georeference Guiana Shield Specimens in the US National Herbarium." Frontiers of BioGeography 2, no. 3 (2010): 71-77.

Goode, George Brown, ed., Smithsonian Institution, 1846-1896: The History of Its First Half Century. Washington, 1897.

Graham, Catherine H. et al., "New Developments in Museum-Based Informatics and Applications in Biodiversity Analysis." Trends in Ecology and Evolution 19, no. 9 (2004): 497-503.

Graves, Gary R. "Costs and Benefits of Web Access to Museum Data." Trends in Ecology and Evolution 15, no. 9 (2000): 374.

Harper, Charles A. Development of the Teacher's College in the United States. Bloomington, IL: McKnight \& McKnight, 1935.

Hickey, Joseph J. and Daniel W. Anderson. "Chlorinated Hydrocarbons and Eggshell Changes in Raptorial and Fish-Eating Birds."Science, New Series 162, no. 3850 (1968): 271-273.

Hoberg, E. P., P.A. Pilitt, and K. E. Galbreath. "Why Museums Matter: A Tale of Pinworms (Oxyuroidea: Heteroxynamatidae) Among Pikas (Ochotona Pinceps and O. Collaris) in the American West." Journal of Parasitology 95, no. 2 (2009): 490-501.

Hoffmaster, Alex R., et al., "Molecular Subtyping of Bacillus Anthracis and the 2001 Bioterrorism-Associated Anthrax Outbreak, United States." Emerging Infectious Diseases 8, no. 10 (2002): 1111-1116.

Howard, L. O. "Biographical Memoir of Stephen Alfred Forbes 1844-1930." Paper presented at the National Academy of Sciences Annual Meeting in 1931. 
http://www.nasonline.org/publications/biographical-memoirs/memoirpdfs/forbes-stephen.pdf.

Hunner, Jon. "Historic Environment Education: Using Nearby History in Classrooms and Museums." The Public Historian 33, no.1 (2011): 33-43.

Keeney, Elizabeth B. Botanizers: Amateur Scientists in Nineteenth-Century America. Chapel Hill: University of North Carolina Press, 1992.

Kohlstedt, Sally Gregory, ed., Origins of Natural Science in America: The Essays of George Brown Goode. Washington D.C. : Smithsonian Institution Press, 1991.

Krahn, Margaret M. et al., "Effects of Age, Sex and Reproductive Status on Persistent Organic Pollutant Concentrations in Southern Resident Killer Whales."Marine Pollution Bulletin 58 (2009): 1522-1529.

Library of Congress. "Documentary Chronology of Selected Events in the Development of the American Conservation Movement, 1847-1920.” Accessed January 1, 2014. http://memory.loc.gov/ammem/amrvhtml/conshome.html.

Liu, Jianguo, et al., "Coupled Human and Natural Systems." AMBIO: A Journal of the Human Environment 36, no. 8 (2007): 639-649.

Lovely, Robert Allyn. "Mastering Nature's Harmony: Stephen Forbes and the Roots of American Ecology.” PhD diss., University of Wisconsin, Madison, 1995.

Mark Carnall. "How to Find and Research Biological Specimens in UK Museums," UCL Museums and Collection Blog, March 27, 2013. http://blogs.ucl.ac.uk/museums.

Marsh, George P. Man and Nature. Seattle: University of Washington Press, 2003.

McPherson, Angie. "What a Hoot: Snowy Owls Make Rare Southern Appearance," National Geographic, January 22, 2014. Accessed August 24, 2014. http://news.nationalgeographic.com/news/2014/01/140122-snowy-owl-southunited-states-irruption-migration-photos-science/.

Miller, Craig R. and Lisette P Waits. "The History of Effective Population Size and Genetic Diversity in the Yellowstone Grizzly (Ursusarctos): Implications for Conservation."Proceedings of the National Academy of Sciences of the United States of America 100, no.7 (2003): 4334-4339.

Monnahan, Cole C. "Do Ship Strikes Threaten the Recovery of Endangered Eastern North Pacific Blue Whales?" Marine Mammal Science 31, no. 1 (2014): 279, doi: $10.1111 / \mathrm{mms} .12157$. 
Murphey, Paul C. et.al., "Georeferencing of Museum Collections: A Review of Problems and Automated Tools, and the Methodology Developed by the Mountain and Plains Spatio-Temporal Database-Informatics Initiative (Mapstedi).” PhyloInformatics; Journal for Taxonomists 3 (2004): 1-29.

National Institute of History. "Deciphering the Genetic Code: Gregor Mendel: The Father of Modern Genetics.” Accessed January 1, 2014. http://history.nih.gov/exhibits/nirenberg/HS1_mendel.htm

Orosz, Joel J. Curators and Culture: The Museum Movement in America, 1740-1870. Tuscaloosa: University of Alabama Press, 1990.

Peakall, David B. “DDE: Its Presence in Peregrine Eggs in 1948.” Science 183, no. 4125 (1973): 673-674.

Place, Linna Funk et al., "The Object as Subject: The Role of Museums and Material Culture Collections in American Studies." American Quarterly 26, no. 3 (1974): 281-294.

Ponder, W. F. et al., "Evaluation of Museum Collection Data for Use in Biodiversity Assessment." Conservation Biology 15, no. 3 (2001): 648-657.

Pyke, Graham H. and Paul R. Ehrlich. "Biological Collections and Ecological/Environment Research: A Review, Some Observations and a Look to the Future." Biological Reviews 85 (2010): 247-266.

Ratcliffe, D. A. "Decrease in Eggshell Weight in Certain Birds of Prey." Nature 215, no. 5097 (1967): 208-210.

Ratcliffe, D.A. "Changes Attributable to Pesticides in Egg Breakage Frequency and Eggshell Thickness in Some British Birds.” Journal of Applied Ecology 7, no. 1 (1970): 67-115.

Rice, Danielle. "Balancing Act: Education and the Competing Impulses of Museum Work." Art Institute of Chicago Museum Studies 29, no. 1 (2003): 6-19.

Robbirt, Karen M. et al., "Validation of Biological Collections as a Source of Phonological Data for Use in Climate Change Studies: A Case Study with the Orchid Ophrys Sphegodes.” Journal of Ecology 99 (2011): 235-241.

Rodriguez, Alejandro and Miguel Delibes. "Current Range and Status of the Iberian Lynx Felis Pardina Temminck, 1824 in Spain.” Biological Conservation 61 (1992): 189-196. 
Sanderson, Glen C. and Frank C. Bellrose, "A Review of the Problem of Lead Poisoning in Waterfowl," Special Publication Number 4, Champaign, Illinois: Natural History Survey (1986).

Schidgen, Henning. “The Laboratory.” European History Online, August 8, 2011, http://ieg-ego.eu/en/threads/crossroads/knowledge-spaces/henning-schmidgenlaboratory\#TheLaboratoryRevolutionofthe19thCentury.

Schnalke, Thomas. “Out of the Cellar.” Nature 471, no. 7340 (2011): 576-577.

Shaffer, Bradley H., Robert N. Fisher, and Carlos Davidson. "The role of natural history collections in documenting species declines." Trends in Ecology and Evolution 13, no. 1 (1998): 27-30.

Steinbacher-Kemp, William F. “The Illinois Natural History Society: 1858-1971." (master's thesis, Illinois State University, 2000).

Stine, Jeffrey K. "Placing Environmental History on Display." Environmental History 7 , no. 4 (2002): 566-588.

Stockholm Convention "History of the Negotiations of the Stockholm Convention,", accessed August 16, 2014.

http://chm.pops.int/TheConvention/Overview/History/Overview/tabid/3549/Defa ult.aspx

Suarez, Andrew V. and Neil D. Tsutsui."The Value of Museum Collections for Research and Society." BioScience 54, no. 1 (2004): 66-74.

"Transactions of the Illinois State Agricultural Society, With Notices and Proceedings of County Societies, and Kindred Association," ed. John P. Reynolds. Volume IV 1859-1860, (Springfield: Bailhache \& Baker, Printers, 1861).

"Transactions of the Natural History Society: For the Year 1860, "Natural History in Schools" Read before the Illinois State Teacher's Association, at Quincy, December 25, 1860 by A. M. Gow, of Dixon, Illinois," ed. C. D. Wilber, Secretary (Springfield, IL: Bailhache \& Baker, Printers, 1861). Accessed August 14, 2014, http://babel.hathitrust.org/cgi/pt?id=hvd.32044106211964;view=1up;seq=107.

United States Geological Survey. "The Four Great Surveys of the West," Accessed September 6, 2014.

http://pubs.usgs.gov/circ/c1050/surveys.htm

Wandeler, Peter, Paquita E.A. Hoeck, and Lukas F. Kellar. "Back to the Future: Museum Specimens in Population Genetics." Trends in Ecology and Evolution 22, no. 12 (2007): 634-642. 
Watson, Elmos Scott, ed. The Professor Goes West: Illinois Wesleyan UniversityReports of Major John Wesley Powell's Explorations: 1867-1874. Bloomington, IL: Illinois Wesleyan University Press, 1954.

Westermark, T., T. Odsjo, and A.G. Hohnels, "Mercury Content in Bird Feathers Before and After Swedish Ban on Alkyl Mercury in Agriculture," Ambio 4 (1975): 8792.

Winker, Kevin. "How to Bring Data Into the Net.” Nature 401 (1999): 524.

Winkler, Kevin. "Natural History Museums in a Postbiodiversity Era."BioScience 54, no. 5 (2004): 455-459.

World Health Organization, "Global Malaria Programme: The Use of DDT in Malaria Vector Control. WHO Position Statement," World Health Organization, Global Malaria Programme, 2011.

Worster, Donald. A River Running West: The Life of John Wesley Powell. Oxford: Oxford University Press, 2001.

Yakel, Elizabeth. "Museums, Management, Media, and Memory: Lessons from the Enola Gay Exhibition." Libraries \& Culture 35, no. 2 (2000): 278-31 